\title{
Financial Distress, Stock Returns, and the 1978 Bankruptcy Reform Act.
}

\author{
Dirk Hackbarth \\ Boston University \\ Rainer Haselmann \\ Goethe University Frankfurt
}

David Schoenherr

London Business School

\begin{abstract}
We study distress risk premia around a bankruptcy reform that shifts bargaining power in financial distress from debtholders to shareholders. We find that the reform reduces risk factor loadings and returns of distressed stocks. The reform effect is stronger for firms with lower firm-level shareholder bargaining power. An increase in credit spreads of riskier relative to safer firms, in particular for firms with lower firm-level shareholder bargaining power, confirms a shift in bargaining power from bondholders to shareholders. Out-of-sample tests reveal that a reversal of the reform's effect leads to a reversal of factor loadings and returns. (JEL G12, G14, G33, K39)
\end{abstract}

The nature of Chapter 11 makes bargaining an important factor in distressed reorganizations, both in formal bankruptcy and in out-of-court renegotiations. Gilson. John, and Lang 1990, Asquith. Gertner, and Scharfstein 1994), Franks and Torous (1994), and Betken (1995) provide empirical evidence that bargaining power of equityholders in debt restructurings affects the incidence of formal and informal reorganizations, deviations from absolute priority, and debt recoveries. Consistent with Hart and Moore 1994), who show that equityholders of distressed firms default to renegotiate debt even when they can make contractual payments, Davydenko and Strebulaev 2007) find

We are grateful to Geert Bekaert (the editor), three anonymous referees, Murillo Campello, Tarun Chordia, Julian Franks, Lorenzo Garlappi, Francisco Gomes, Jens Hilscher, Kose John, Tim Johnson, Robert Lawless, Kai Li, Lynn LoPucki, Ralph Koijen, Erwan Morellec, Ali Ozdagli, Kjell Nyborg, Katharina Pistor, Philip Valta, Viktrant Vig, Alexander Wagner, Christian Wagner, Ivo Welch, Hong Yan, and seminar participants at the 2011 DGF Meetings; the 2011 Conference on Financial Economics and Accounting; the 2011 Symposium on Finance, Banking, and Insurance; the 2014 SGF Conference; the 2013 WFA Meetings; New York University; University of Bonn; University of Illinois; University of Lausanne; University of Notre Dame; University of Southern California; and University of Zurich for comments and suggestions. Special thanks to the Hon. Samuel Bufford for providing us with details regarding the 1978 Bankruptcy Code and to Jens Hilscher, Francis Longstaff, and Kevin Murphy for pointing us to and providing us with data. Supplementary data can be found on The Review of Financial Studies web site. Send correspondence to Dirk Hackbarth, Finance Department, Boston University, 595 Commonwealth Avenue, Boson, MA 02115, USA; telephone: (617) 358-4206; facsimile: (617) 353-6667. E-mail: dhackbar@bu.edu.

(C) The Author 2015. Published by Oxford University Press on behalf of The Society for Financial Studies. All rights reserved. For Permissions, please e-mail: journals.permissions@oup.com. doi:10.1093/rfs/hhv009

Advance Access publication February 3, 2015 
that shareholders can extract surplus that may extend beyond recoveries in liquidity default, due to their decision about whether and when to default (i.e., strategic default). To the extent that stock returns reflect expected recoveries in liquidity defaults and expected benefits from strategic default, they too should depend on the bargaining power of equityholders of firms in financial distress.

This paper analyzes the consequences of an exogenous variation in equityholders' bargaining power relative to debtholders on distress risk premia. The modifications of Chapter 11 by the 1978 Bankruptcy Reform Act (hereafter, BRA) constitute a material change in the bankruptcy code. One of the main consequences of the BRA is a change in the distribution of bargaining power in distressed renegotiations 1 A higher level of bargaining power increases shareholders' expected recoveries and thus also affects the value of the option to default (see, for example, Bebchuk 2002) 2 We document a significant decline in risk premia for distressed stocks after the passing of the BRA. Additionally, differences in distress risk premia for firms with different levels of characteristics that proxy for firm-level shareholder bargaining power disappear after the reform. Thus, an increase in reform-based shareholder bargaining power attenuates the impact of partly substitutable firm-specific shareholder bargaining power on distress risk premia. Finally, credit spreads increase after the BRA, particularly in case of low firm-level shareholder bargaining power before the reform, further indicating a shift in bargaining power from creditors to debtors.

The BRA influenced distressed reorganizations under Chapter 11 by, for example, changing the voting rules of a reorganization plan, introducing "cramdown" reorganization, and changing the conditions for voluntary filing White 1989; Klee 1979). Shareholders of distressed firms benefited from these changes in several ways. In cases of liquidity default, debtors expect higher recovery rates. In addition, there is an incentive to renegotiate debt by defaulting strategically, which provides a credible threat in out-of-court restructuring. Following the BRA, the incidence of corporate bankruptcy filings by firms opting for reorganization increases and shareholders of financially distressed firms achieve higher deviations from the Absolute Priority Rule (APR) in bankruptcy proceedings Franks and Torous 1989: Eberhart, Moore, and Roenfeldt 1990; Weiss 1990) as well as higher concessions from debtholders in out-of-court restructurings (Franks and Torous 1994). Because the codification was complex Klee 1980 and it was difficult for market participants to anticipate the interpretation of the new code by bankruptcy judges, the reform's

1 In cross-country studies, Davydenko and Frank 2008) and Diankov et al 2008) establish empirically that the design of bankruptcy codes affects the bargaining power of creditors and debtors in financial distress. Stock returns of firms in financial distress are particularly sensitive to the expected outcome of distress resolution. Thus, a major change in the bankruptcy code should be of first-order importance in the context of our analysis.

2 A large body of corporate finance literature documents that debtors can extract concessions from creditors to reach agreements that avoid costly bankruptcy proceedings, the destruction of debt value, or the delaying of repayments Franks and Torous 1989; Eberhart, Moore, and Roenfeldt 1990: Weiss 1990. 
actual (i.e., positive) effect on shareholder bargaining power, both in formal bankruptcy and in private workouts, was hard to predict.

The BRA allows us to test predictions for distress risk premia from a simple and widely used capital structure model with strategic debt service 3 The adverse consequences of financial distress for shareholders should decline if they can extract more from distressed firms after the reform (for example, APR violations). Hence, returns and risk factor loadings of distressed firms should decrease relative to those of less distressed firms. We observe a significant decline of distress risk premia and risk measures of distressed stocks. A longshort portfolio buying the most distressed quintile of stocks and selling the least distressed quintile yields average monthly returns of $2.59 \%$ before, and an insignificant $0.08 \%$ after, the BRA. Controlling for common risk factors, the monthly alphas of the long-short portfolio are $0.51 \%$ before and $-0.35 \%$ after the BRA, implying a decline of $0.86 \%$. This is more than half of the average monthly alpha of $1.64 \%$ for the quintile of the most distressed stocks before the reform. Similarly, the long-short portfolio's loadings on the market, size, and value factors decrease significantly after the reform.

To interpret these findings the factor models must adjust for systematic determinants of stock returns for high- and low-risk firms, except for the BRA. To mitigate the possibility of confounding the effects of the BRA with unrelated shocks, we predict that the cross-section of firms should be differentially affected by the reform, depending on their firm-specific level of shareholder bargaining power. Prior research documents that in firms with high levels of inside ownership, managers act more in the interests of shareholders and that firms with low asset tangibility are difficult to liquidate Alderson and Betken 1996; Acharya, Bharath, and Srinivasan 2007; Davydenko and Strebulaev 2007) 4 Shareholders of such firms already have a higher level of shareholder bargaining power before the BRA and hence benefit less from the reform. Therefore, we expect the BRA to have a differential impact on the change in the riskiness of distressed stocks depending on firm-level proxies of shareholder bargaining power. By exploiting cross-sectional heterogeneity in firm-specific bargaining power, we can rule out that our results are driven by confounding events that can explain a reduction in distressed stocks' riskiness after the reform, but affect firms with different levels of shareholder bargaining power equally.

Firms with higher shareholder bargaining power exhibit consistently lower capital asset pricing model (CAPM) betas during the pre-reform period. If the BRA is largely a substitute for this firm-specific channel, then this channel

3 See, for example, Fan and Sundaresan 2000), Francois and Morelled 2004), Davydenko and Strebulaev 2007), Hackbarth, Hennessy, and Leland 2007), Garlappi, Shu, and Yan 2008), Favara, Schroth, and Valta 2012, and Valta Forthcoming). Extensions to allow for intensity-based, non-strategic default do not alter our predictions for risk premia of distressed firms.

4 Additionally, firm size and R\&D ratio have been identified as important proxies for shareholder bargaining power in distressed reorganizations. 
should be economically and statistically less important after the reform. Indeed, cross-sectional differences in betas of distressed stocks are significantly smaller during the post-reform period. These cross-sectional results support the view that the change in shareholder bargaining power due to the BRA drives the change in distress risk premia.

In addition, we examine credit spreads, to ensure that our results are not due to a general decline in distress risk premia in the 1980s. There is a long-lasting increase of the Moody's Baa over Aaa credit spread after the passing of the reform, which is consistent with the findings on small business loan pricing by banks after the BRA in Scott and Smith 1986) 5 This suggests that creditors of distressed firms increase their return expectations after the BRA, as the BRA weakens their position in financial distress. We adopt the cross-sectional approach in Davydenko and Strebulaev 2007) to test whether the increase in credit spreads is significantly larger for firms with lower shareholder bargaining power before the BRA. We find that credit spreads rise more for firms whose equity risk premia decline more. The concurrent decrease in risk premia for equityholders and increase in risk premia for debtholders implies a shift in the bearing of distress risk from debtors to creditors.

To reinforce the interpretation of our main findings, we conduct outof-sample tests. In the early 1990s, several changes in bankruptcy proceedings shifted bargaining power back toward creditors (see, for example, Skeel 2003: Ayotte and Morrison 2009;: Bharath. Panchapegesan. and Werner 2010). For example, Bharath. Panchapegesan, and Wernen 2010) document a sharp reduction in APR violations. The reversal of some of the reform's effects provides a laboratory to test the implications of changes in shareholder bargaining power out of sample. While returns and factor loadings of distressed over safe stocks during the 1985-1989 period are comparable to those observed in the early 1980s, they increase significantly in the 1990s, back to levels similar to those seen before the BRA. Consistent with the regain in bargaining power by creditors in the early 1990s, the Baa over Aaa spread decreases during this period. This evidence lends further support to the view that the change in shareholder bargaining power induces the change in distress risk borne by shareholders.

A number of robustness tests support our findings. The fact that characteristics of distressed stocks, such as CAPM beta and return volatility, are lower after the reform confirms a reduction in the risk borne by shareholders and eliminates the concern that lower stock returns merely reflect surprise on the part of investors who expected higher returns on distressed stocks. We study a hand-collected sample of bankruptcy cases for which actual APR violation values are available, and find reliably lower stock returns for distressed firms with ex post higher deviations from absolute priority. Firm-level analysis allows

5 Rodano, Serrano-Velarde, and Tarantino 2014 observe similar results for an Italian bankruptcy law reform. 
us to control for characteristics that might bias our portfolio-level results — for example, industry fixed effects. Switching from monthly to annual updating of default risk portfolios yields qualitatively identical results. Finally, the reform effect obtains for both value-weighted and equal-weighted portfolio returns and is robust to controlling for recessions.

\section{The Bankruptcy Reform Act of 1978}

In this section, we first outline the most important changes due to the BRA with respect to shareholder bargaining power in Chapter 11. We then describe the legislative history of this reform. A thorough understanding of when investors realized that the BRA would affect their bargaining power is essential for designing our event windows, and to disentangle changes in discount rates (expected returns) from short-term valuation effects induced by changes in investor expectations.

\subsection{The BRA of 1978 and shareholder bargaining power}

On November 6, 1978, President Carter signed the BRA into law, replacing as of October 1, 1979, the Chandler Act of 19386 According to Posnen 1997), bankruptcy law under the Chandler Act was considered complicated and intolerably ambiguous, especially since the underlying laws were vague (see King 1979) for a detailed comparison of Chapter 11 to the pre-1978 bankruptcy laws). For this reason, large creditors and bankruptcy lawyers pushed for a reform in the bankruptcy code. The legislative history of the BRA spanned more than a decade, and due to the complexity of the codification, it was hard for lawmakers to foresee all the effects of the reform on shareholder bargaining power in bankruptcy proceedings.

While liquidation proceedings were hardly affected by the BRA, reorganization under Chapter 11 was amended considerably 7 Under Chapter 11 , the "debtor in possession" continues the firm's operations. This leaves existing management in control, and rearranges the firm's debt structure under a plan Klee 1979). There are several procedures for formulating a plan that differ considerably from the pre-1978 bankruptcy code White 1983, 1989). First, under the old code, a reorganization plan had to be approved by majority vote of all unsecured creditor classes. In contrast, the BRA provides two manners of voting to qualify for confirmation of the reorganization plan. The first is a vote in favor of the plan by a majority of members of each class (holding two-thirds of the debt or equity in that class). As White 1989, 139) states: "For each class of creditors, the required voting margin in favor is at least two-thirds in amount

6 We use Roman numerals to refer to pre-BRA chapters and Arabic numerals for post-BRA chapters.

7 The debtor-in-possession model of reorganization was enacted as Chapter XI in 1938, and provided only for the restructuring of unsecured debt. The alternative, Chapter X, was highly unpopular, and chosen very infrequently White 1983). In 1978, Chapter XI was used as a basis for Chapter 11, and Chapter X was abandoned. 
of claims and one-half in number of claimants. For equity, the required voting margin is at least two-thirds in amount. Thus reorganization plans ... provide for a different division of the firm's assets than would occur under the APR liquidation rules" since every class "must receive something" to vote in favor of the plan. "Under the APR, equity and low priority creditors may quite possibly receive nothing at all." At the same time, management has the exclusive right to propose a plan for 120 days (and extensions to this exclusivity period are commonly granted) to encourage reorganization of the firm 8

Second, another novelty of Chapter 11 is "cramdown" reorganization? If no plan can be agreed upon, under "cramdown" reorganization, the firm continues operating while a buyer is sought for all or part of it as a going concern (see Klee 1979) for details). "Cramdown" plans are subject to court-imposed discount rates and result in higher transaction costs compared with regular plans since the court typically requires appraisals by outside experts. It is considered complicated and costly and therefore acts as a disciplinary tool in negotiations. As such, Chapter 11's role is to "bring the parties to the bargaining table" Broude 1984), to "negotiate a plan even to the point that those holding senior interests allow junior interests to realize some distribution" King 1979.). Neither confirmation of a reorganization plan by majority vote or "cramdown" is statutorily preferred: a party may freely choose either alternative, although the "cramdown" procedure is much more expensive and time-consuming, and requires additional evidence.

Third, the conditions under which firms can voluntarily file for Chapter 11 changed. The pre-1978 law required a firm to be insolvent to file for Chapter $\mathrm{XI} 10$ Under the new code, "Chapter 11 does not require that a debtor be insolvent in order to qualify for reorganization" Bradley and Rosenzweig 1992.). "Such grounds of bankruptcy as insolvency no longer need to be shown in fact, a debtor company may file for Chapter 11 for any legitimate business purpose" Kaplan 1987. This change enables debtors to use the threat of Chapter 11 as a strategic tool against creditors, as will be outlined below.

Overall, the intention of the BRA was to balance the rights of creditors and debtors. However, debtors were effectively able to use the new bankruptcy legislation to better accomplish their own interests. LoPucki 1995) writes that "it also can be seen, in retrospective, that Chapter 11 gave debtors more control than necessary or appropriate." The sole right to propose a plan combined with the modified voting procedures and the threat of "cramdown"

8 H.R. Rep. 595, 95th Cong., 1st Sess. 232 (1977): "In most cases, 120 days will give the debtor adequate time to negotiate a settlement, without unduly delaying creditors." However,Weiss and Wruck 1998) argue that this is one of the two major reasons for why Chapter 11 exacerbates agency problems. Their case study of "Eastern Airlines" is an example of the failure of Chapter 11 to protect debtholders by facilitating wealth transfers to equityholders.

9 Chapter X featured "cramdown" reorganization, but it was hardly used King 1979).

10 See Bradley and Rosenzweig 1992 note 6): "Compare Bankruptcy Act of 1898, paragraph 130(1), 323, 423, as amended by 11 U.S.C. paragraph 520, 723, 823 (1971) (requiring insolvency)." 
place management and hence equity in an excellent bargaining position in negotiations over the reorganization plan. Consequently, creditors are willing to accept a plan that violates absolute priority in favor of equity, or to give up part of their claims in out-of-court restructuring to avoid a bankruptcy filing.

Since the codification was complex, it was difficult for lawmakers to foresee the actual effects of this reform on the bargaining power of the various parties involved in the bankruptcy process 11 Klee 1980 emphasizes that the BRA was not enacted in a simple procedure, and given that it was such a major piece of legislation, the official documentation process was opaque. Bankruptcy judges were biased in favor of reorganization LoPucki and Whitford 1990). Therefore, they typically extended the exclusivity period, originally meant to be limited to 120 days to prevent equity from abusing it to dilute creditor claims. Accordingly, Kerkman 1987) states that creditor rights implemented in the law were poorly enforced by bankruptcy judges 12

While claimants could hardly evade APR before 1978, the new code was intended to facilitate consensus concerning reorganization plans (LoPucki and Whitford 1990) and relaxed adherence to APR. More specifically, the BRA leaves the decision about the reorganization value of the firm to a process of bargaining among managers, equityholders, and different classes of creditors Bebchuk and Chang 1992; Bebchuk 1998. Several papers empirically document APR violations as an implication of the BRA Franks and Torous 1989; Eberhart, Moore, and Roenfeldt 1990; Weiss 1990. Franks and Torous 1989 "conjecture from the provisions of the 1978 code and from conversations with lawyers and a bankruptcy judge that deviations from absolute priority have increased as a result of the 1978 Act." LoPucki and Whitford 1990) document considerable distributions to equityholders of insolvent debtors as a consequence of bankruptcy reorganization of large, publicly held companies. They argue that payments made to equity are not justified by financial or legal considerations but result from the increased bargaining power of equity in Chapter 11. In addition to deviations from the APR in Chapter 11 cases, Franks and Torous 1994) establish that creditors are willing to accept even larger APR violations in distressed exchanges to avoid bankruptcy filings. Thus, the new Chapter 11 can be regarded as an important tool for managers and shareholders to settle disputes with creditors even if the firm is still solvent.

The increase in bargaining power for shareholders as a consequence of the BRA results in a rise of bankruptcy filings, especially by debtors filing for reorganization (Table 1 columns 1 and 3). Besides the sharp increase in total filings following the BRA, the proportion among these firms filing for Chapter 11 also rises considerably (last column of Table 1 .

11 Posnet 1997) outlines in detail the role of different interest groups during the formation of the BRA.

12 For instance, creditors received the right to propose a reorganization plan after the exclusivity period elapsed. But bankruptcy judges were reluctant to terminate the exclusivity period early, which impeded creditors' position, and debtors were successful in "dictating the terms of reorganization to their creditors" LoPucki 1983). 
Table 1

Bankruptcy code petitions commenced by chapter of the bankruptcy code

\begin{tabular}{|c|c|c|c|c|c|c|}
\hline Year & $\begin{array}{l}\text { Total } \\
\text { filings } \\
\text { (1) }\end{array}$ & $\begin{array}{l}\text { Chapter VII } \\
\text { or Chapter } 7 \\
\text { (2) }\end{array}$ & $\begin{array}{c}\text { Chapter X } \\
\text { (3) }\end{array}$ & $\begin{array}{c}\text { Chapter XI } \\
\text { or Chapter } 11 \\
(4)\end{array}$ & $\begin{array}{c}\text { Active firms } \\
\text { in CRSP } \\
(5)\end{array}$ & $\begin{array}{c}\% \text { Chapter X and XI } \\
\text { or Chapter } 11 \\
\text { of total filings } \\
{[(3)+(4)] /(1)}\end{array}$ \\
\hline 1972 & 182,860 & 153,934 & 82 & 1,361 & 2,650 & $0.79 \%$ \\
\hline 1973 & 173,197 & 145,914 & 89 & 1,458 & 3,964 & $0.89 \%$ \\
\hline 1974 & 189,513 & 157,967 & 152 & 2,171 & 4,002 & $1.22 \%$ \\
\hline 1975 & 254,484 & 209,330 & 169 & 3,506 & 4,038 & $1.44 \%$ \\
\hline 1976 & 246,549 & 209,067 & 116 & 3,235 & 4,101 & $1.36 \%$ \\
\hline 1977 & 214,399 & 181,194 & 86 & 3,046 & 4,157 & $1.46 \%$ \\
\hline 1978 & 202,951 & 168,771 & 63 & 3,266 & 4,183 & $1.64 \%$ \\
\hline 1979 & 226,476 & 183,259 & 51 & 3,042 & 4,222 & $1.37 \%$ \\
\hline $1980 *$ & $210,359 *$ & $159,346 *$ & & $4,119 *$ & 4,342 & $1.96 \% *$ \\
\hline 1981 & 360,327 & 265,721 & & 7,823 & 4,743 & $2.17 \%$ \\
\hline 1982 & 367,858 & 255,095 & & 14,058 & 4,995 & $3.82 \%$ \\
\hline 1983 & 374,726 & 251,319 & & 21,206 & 5,380 & $5.66 \%$ \\
\hline 1984 & 344,262 & 232,991 & & 19,913 & 5,801 & $5.78 \%$ \\
\hline
\end{tabular}

This table lists total bankruptcy filings, Chapter VII/7 filings, Chapter X, and Chapter XI/11 filings by year. The last two columns show the number of active firms in CRSP and the fraction of reorganization filings in total bankruptcy filings. The numbers for each year are filings from July of the previous year to June of the respective year. Cases filed prior to October 1, 1979, are under the old bankruptcy code, and those filed on or after October 1, 1979, are under the new BRA. Column (5) shows the number of active firms in the CRSP database in each year. * reflects figures from 9 months only (November 1979 to June 1980).

Source: The Administrative Office of the United States Courts - Table F-2.

\subsection{The BRA's legislative history and event windows}

The reform's legislative process began in 1968 when a subcommittee of the Senate Judiciary Committee first held hearings to discuss a new bankruptcy code. Only in January 1977 was a proposal for a new legislation previously worked out by the Commission on the Bankruptcy Law introduced to the Senate and the House of Representatives. The legislative process between this date and the passing of the law was characterized by extreme uncertainty regarding both the timing and the potential effects of the reform on the relative bargaining power of creditors and debtors. We illustrate this by highlighting some of the most important events during the legislative history of the BRA, a summary of which is provided in Table2 Additionally, Table 3 presents selected newspaper articles from the financial press discussing the BRA and its real effects for bankruptcy proceedings.

On October 27, 1977, the BRA was withdrawn from floor consideration of the House of Representatives after a floor amendment (the so-called DanielsonRailsback Amendment) cut the essence out of the reform. Consequently, there was uncertainty about whether the BRA would be enacted 13 After the vote on this amendment was reversed on February 1, 1978, it was still unclear

13 See Table 3 for example, according to the Washington Post's articles "Probe asked of criminals' use of bankruptcy laws," November 30,1977, and "Bankruptcy reforms criticized by jurists," December 5, 1977, it was clearly uncertain whether the new bankruptcy bill would be enacted. 
Table 2

Important events around the introduction of the BRA

Date

Throughout 1968 Hearings on review of bankruptcy law by Senate Judiciary Committee

July 24,1970

July 30,1973

1974 to 1976

Jan. 4, 1977

July 11, 1977

Sept. 8, 1977

Oct. 27,1977

Formation of Commission on the Bankruptcy Law by Congress

Commission report including proposed statutes is filed to Congress

Intensive study (including hearings) in bankruptcy legislation in House and Senate

Edwards and Butler introduce new bill H.R. 6 to House of Representatives

After adopting more than 100 amendments and comments from the bench, the bar, and academicians, the new bill H.R. 8200 is presented for consideration by House of Judiciary Committee

House of Judiciary Committee vote for H.R. 8200 after adopting several amendments

Floor consideration of H.R. 8200 in the House of Representatives; H.R. 8200 is withdrawn from floor consideration as Danielson-Railsback Amendment passes

Oct. 31,1977

Feb. 1, 1978

Senate introduces alternative version of H.R. 8200, named S. 2266

Reversal of the vote for the Danielson-Railsback Amendment; H.R. 8200 passes House of Representatives and is sent to Senate

Summer 1978

There is doubt whether the bill could be passed before adjournment of the 95th Congress (set for October 14th 1978); if not, entire process will have to start afresh in the 96th Congress in 1979

Aug. 10, 1978

Senate Finance Committee reports S. 2266 after including several amendments from Joint Committee of Taxation

Sept. 7, 1978

Sept. 28,1978

Senate adopts amendments in S. 2266; now there are significant differences in the substantive law (e.g., on exemptions, reaffirmation, as well as reorganization procedure)

House of Representatives includes amendments to obtain convergence with Senate version of the bill; intervention by chief justice to thwart passing of the bankruptcy legislation preventing consideration by the Senate

Oct. 5,1978

After special-interest groups (e.g., SEC, commodities industry, consumer finance industry) lobbies senators, further amendments are included in the bill before it is passed to House

Oct. 6,1978

Unanimous consent to take H.R. 8200 is first denied by House, but the bill is eventually passed by House in the late afternoon

Oct. 25,1978

Nov. 6, 1978

Oct. 1,1979

Aug. 26, 1982

Sept. 29,1983

Securities and Exchange Commission and chief justice urge president to veto the bill

President signs BRA (last day it could have been signed into law)

BRA becomes effective

Bankruptcy of Manville: It earned $\$ 60$ million in previous year, and its net worth on June 30 was $\$ 1.1$ billion, compared with combined short-and long-term debt of $\$ 600$ million Frank Lorenzo (CEO) takes Continental into Chapter 11 bankruptcy; union leaders say Continental and other companies that have enough cash to stay in business are abusing the bankruptcy law; Continental, for its part, is also seeking relief from its banks and other creditors

Sources: Klee 1980, Posne 1997, various newspaper articles in Table 3

whether the House and Senate would converge on a common bill during the 95 th Congress. The vote in favor of a bankruptcy reform succeeded only in one of the last sessions of the 95th Congress (September 28, 1978). Any further deferral in this process would have meant that the entire process had to start afresh in the 96th Congress in 1979. Even after the House voted in favor of the new bill, several parties tried to prevent the BRA from being passed. In particular, the Securities and Exchange Commission (SEC) and chief justice strongly urged President Carter to veto the bill Kled 1980. Eventually, the president signed the bill into law on the last possible day, November 6, 1978.

The event window for our empirical analysis should capture changes in discount rates (expected returns) purified of short-term valuation effects induced by contemporaneous shifts in investors' expectations. We verify that pre-reform returns of distressed firms are not biased upward by conducting an 
Table 3

Newspaper articles concerning the passing of the BRA

Date

Paper, Headline

Content

Nov. 30, $1977 \quad$ Washington Post, "Probe Asked of Criminals' Use of Bankruptcy Laws"

Dec. 05, 1977

Washington Post, "Bankruptcy Reforms Criticized by Jurists"

Nov. 15,1978

Wall Street Journal, "Going for Broke"

Oct. 19,1979

New York Times, "New Bankruptcy Law: Creditors, Debtors Aided'

Oct. 03,1980

American Banker, "ABA Unit to Study Bankruptcy Act"

Mar. 23, 1981
American Banker, "Legislative Changes May Make Credit Even More Costly"
Both Loomis and Bell, as well as Donald C. Lubick, deputy assistant Treasury secretary for tax legislation, testified in favor of the bankruptcy reform bill introduced last month. The bill is a watered-down version of the House's bankruptcy reform which was withdrawn after a floor amendment cut the essence out of it. ... Political reality, a staffer said, dictated such a bill would never pass.

The National Bankruptcy Conference last week assailed a Senate sub-committee's attempt bankruptcy reform, calling it "clearly deficient." The blue-ribbon group of judges-law professors and attorneys specializing in bankruptcy cases told members of the Subcommittee on Improvements in Judicial Machinery that the bill "does nothing to better the existing system [and] in some instances actually represents a step backward."

Corporate-bankruptcy lawyers believe that consolidated chapter will reduce squabbling, speed reorganizations and improve chances that unsecured creditors and stockholders will realize something on their claim. Critics hold that if trustees are named less often, most reorganizations will be controlled by corporations and their senior creditors, who are those whose claims have priority, usually big lenders like banks and insurance companies.

Corporate creditors and debtors are expected to benefit from Bankruptcy Reform Act of 1978, which took effect on October 1, 1979. In business bankruptcies, particularly in reorganization proceedings, law is expected to improve position of major creditors such as banks and insurance companies.

A task force of the American Bankers Association will meet in Washington on Friday to assess the impact of the Bankruptcy Reform Act of 1978. ... It's become a general perception that an unwarranted number of bankruptcies are being declared, and this trend could have the unfortunate effect of restricting the availability of credit.

Bankruptcy, which reached explosive levels during the 1980 recession, should become a major federal issue, as financial institutions cry out for modifications of the Bankruptcy Reform Act of 1978. Many legislators now admit that some aspects of the Bankruptcy Code have become too lenient and significate abuse has become part of the system. 
Table 3

Continued

Date

Paper, Headline

Content

Nov. 15, $1981 \quad$ New York Times, "The Surge in

Sep. 01, 1982

Associated Press, "Bankruptcy Failure Can Mean Survival"

Sep. 10, 1982

New York Times, "Manville Creditors Say the Fight Is Just Beginning"

Nov. 02, 1982

New York Times, "Suits Force Chapter 11"
Finally, the high cost of money is sending tens of thousands of the businesses that borrowed it down the road that so many of the experts said it would to a cleaner called bankruptcy court. ... Alarmed by the tide of bankruptcies, the credit industry insists that the revised act has allowed people to shed debt easily and irresponsibly. The industry is heavily lobbying for Congress to repeal most of the new laws' liberalized provisions.

The [bankruptcy] case of Manville is an unusual one. From the standpoint of its balance sheet, Manville is considered one of the healthiest corporations ever to file for Chapter 11. It earned $\$ 60$ million last year, and its net worth on June 30 was $\$ 1.1$ billion, compared with combined short-and long-term debt of $\$ 600$ million.

The official business of the meeting was to appoint a creditors' committee from among those to whom Manville owed money August 26, the day it filed for protection from its creditors under Chapter 11 of the Federal Bankruptcy Act.

Amatex is solvent. Indeed, in the list of the company's largest creditors that must be a part of every filing, Amatex lists only modest debts.... We are going to continue our operations as before, Mr. Drexel said. We're not going to lay anybody off. The only thing that's going to stop is the lawsuits.... Mr Drexel would not discuss the company's financial situation beyond saying that its assets far outweighed its liabilities.

event study around November 6, 1978 (the signing of the law) 14 The signing of the law resolved uncertainty about the passing of the reform, and stock market reactions on or directly after November 6, 1978, should be informative regarding how investors assessed the BRA.

Results are summarized in Table 4 In Panel A, we report the cumulative abnormal return for stocks in the highest quintile of the default risk measure minus stocks in the lowest quintile of the distress measure. Panel B shows the results from regressing cumulative abnormal returns on a default variable that takes the value of one for the safest $20 \%$ of stocks up to five for the riskiest $20 \%$ of stocks. Around the signing of the law (November 6 to November 7), distressed firms exhibit slightly lower returns relative to safe firms, with $0.16 \%$ for the riskiest minus safest quintile and -0.02 per risk quintile (column

14 We use a standard event study methodology with a market model MacKinley 1997). We estimate CAPM betas for stocks in a 100-day estimation window from 110 to 11 trading days before November 6, 1978. The results are qualitatively identical for different estimation windows (for example, 50 days or 150 days). 
Table 4

Event study: Passing of the BRA

\begin{tabular}{lccc} 
Event window & I & II & III \\
November 6-7 & November 6-8 & November 6-10 \\
\hline Panel A. Top-bottom quintile & -0.16 & $-1.02^{* * *}$ & $-0.80^{* *}$ \\
High-low & {$[0.61]$} & {$[3.50]$} & {$[2.27]$} \\
$t$-statistic & 1242 & 1242 & 1242 \\
Observations & & & \\
\hline Panel B. Risk quintiles & -0.02 & $-0.25^{* * *}$ & $-0.15^{*}$ \\
Default & {$[0.33]$} & {$[3.82]$} & {$[1.88]$} \\
$t$-statistic & 3103 & 3103 & 3103 \\
Observations & &
\end{tabular}

This table depicts the results of regressing the difference between the cumulated realized return of firm $i$ over its return predicted by a market model. The market model is estimated during a 100-day estimation window from 11 to 110 trading days before November 6, 1978. The event window considered in each column is indicated at the top of the table. The entries in Panel A show the difference in the cumulative abnormal return for the riskiest quintile of stocks minus the safest quintile of stocks according to the Campbell, Hilscher, and Szilagvi 2008) default model (1,242 firms in total). The entries in Panel B show the results of regressing the cumulative abnormal return of all 3,103 firms on a default variable that takes the value of one for the safest quintile of firms, two for the next quintile, and up to five for the riskiest quintile of firms. $t$-statistics are reported in parenthesis.

* indicates statistical significance at the $10 \%$ level, ** at the $5 \%$ level, and $* * *$ at the $1 \%$ level.

I). However, the difference is not statistically significant. When we extend the event window to November 8 (column II) or to November 10 (column III), distressed stocks significantly underperform safe stocks after the reform, with $-1.02 \%$ and $-0.80 \%$ for the riskiest over the safest stocks and $-0.25 \%$ and $0.15 \%$ per risk quintile, respectively. Thus, investors expected the new law to benefit creditors rather than debtors. This is consistent with newspaper articles around this date (for example, the New York Times article "New Bankruptcy Law: Creditors, Debtors Aided," from October 19, 1979, identifies creditors as the beneficiaries of the new bankruptcy code). Thus, if anything, the returns of distressed stocks should be biased downward by valuation effects before the BRA.

Additionally, we ensure that post-reform returns are not biased by immediate valuation effects when investors learn about the actual effects of the reform 15 The first newspaper articles from the financial press observing that the BRA benefited debtors came out in the last quarter of 1980 (see, for example, the American Banker article "ABA Unit to Study Bankruptcy Act," on October 3, 1980). By March 1981, reports about abusive uses of the bankruptcy system were widely acknowledged by creditors and legislators (see article by American Banker "Legislative Changes May Make Credit Event More Costly," on March 23, 1981). Thus, investors learned about the effects of the reform on bargaining power between the introduction of the reform (October 1979) and the point when the positive effects of the reform for shareholders was widely accepted based on the evidence from the financial press (March 1981). Any valuation effects should have occurred during the November 1979 to February 1981 period.

15 Although this would lead to an upward bias in returns, which works against the hypothesized predictions. 
We construct symmetric event windows during the period from January 1975 to December 1984. Our pre-event window runs from January 1975 until October 1979. To avoid potential valuation effects during our sample period, we skip the months from November 1979 to February 1981 when investors learned about the effect of the new bankruptcy code on shareholder bargaining power. The post-event period spans from March 1981 until December 1984. In unreported results we verify that the results are qualitatively unaffected if we vary the length of the event windows by up to two years.

\section{Testable Hypotheses}

This section introduces testable hypotheses for stock returns and yield spreads around the reform. We establish the direction of the possible effects of the reform, and identify conditions under which these effects (overall and on the margin) are likely to be stronger or weaker. Appendix A derives the implications of the BRA from a simple and widely used model of strategic debt service 16

Suppose that, irrespective of the reform, stockholders and bondholders of firm $i$ play a Nash bargaining game with respective bargaining power $\eta_{i}$ and $1-\eta_{i}$, which might be determined by firm $i$ 's asset characteristics, complexity of debt structure, and so on. The increase in deviations from absolute priority and the incidence of bankruptcy filings indicate an improvement in the bargaining position of shareholders vis-à-vis creditors due to the BRA. We model this additional bargaining power parameter, which will be obtained by all firms' equityholders due to the reform by $\eta_{r}$, which might be an imperfect complement or substitute for $\eta_{i}$. Thus, we model shareholder bargaining power for firm $i$, after the reform, as $\eta_{i}+\eta_{r}-\gamma_{i} \cdot \min \left\{\eta_{i}, \eta_{r}\right\}$, where $\gamma_{i} \in[0,1]$ allows for firm-level heterogeneity in the reform's effect on the increase in shareholder bargaining power. Though not directly observable, a higher value of $\gamma_{i}$ implies that the reform is more substitutable, and hence firms with higher firm-level shareholder bargaining power do not gain as much as firms with lower firm-level shareholder bargaining power prior to the reform. Intuitively, the value of $\gamma_{i}$ depends on the nature of firm-level bargaining power position of shareholders and its overlap with the specific features of the BRA.

Figure 1 shows the relationship between default probability and expected return, which is determined by equity beta (see Equations A.16 and A.17 in Appendix A). For a set of parameter values, it plots risk-return profiles before the BRA $\left(\eta_{r}=0 \%\right)$ in the first panel and after the BRA $\left(\eta_{r}=20 \%\right)$ in the second and third panels. The dotted line represents zero firm-level

16 Debt renegotiation requires a structural (diffusion) model rather than a reduced-form (intensity) model, which features exogenous (i.e., non-strategic) default. Our predictions derive from strategic default but also obtain in mixed reduced-form and structural models, such as the jump-diffusion model in Leland 2006, when debt renegotiation is feasible, so they are consistent with the possibility of non-strategic default following from intensity-based (jump) risk. 

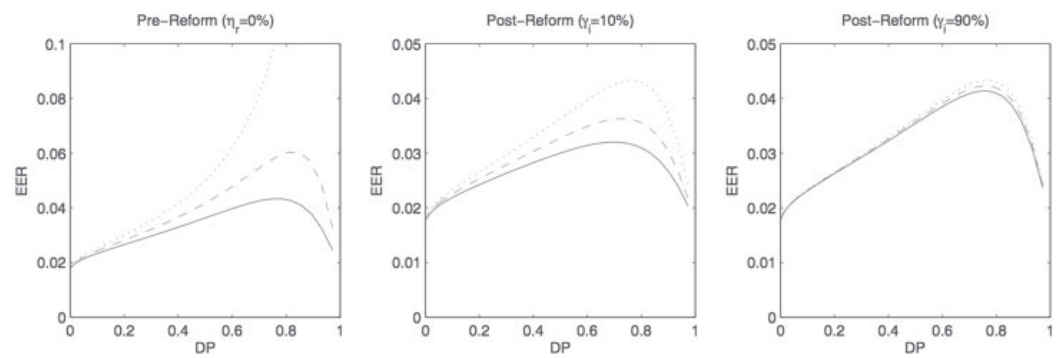

Figure 1

Default probability and expected excess return

This figure plots expected excess return $(E E R)$ in Equation A.16 as a function of default probability $(D P)$ in Equation A.20 before the BRA $\left(\eta_{r}=0 \%\right)$ and after the BRA $\left(\eta_{r}=20 \%\right)$ for firms with no firm-level shareholder bargaining power $\left(\eta_{i}=0 \%\right.$; dotted lines), low firm-level shareholder bargaining power $\left(\eta_{i}=10 \%\right.$; dashed lines), and high firm-level shareholder bargaining power $\left(\eta_{i}=20 \%\right.$; solid lines). Due to the BRA, shareholder bargaining power, $\eta$, rises from $\eta_{i}$ to $\eta_{i}+\eta_{r}-\gamma_{i} \cdot \min \left\{\eta_{i}, \eta_{r}\right\}$. Hence the BRA's effect is more complementary $\left(\gamma_{i}=10 \%\right)$ in the second panel and more substitutable $\left(\gamma_{i}=90 \%\right)$ in the third panel. The graphs vary the level of earnings, $X$, between the initial level, $X_{0}=\$ 20$, and the level at which strategic debt service is initiated, $X_{S}$, for a debt coupon payment of $C=\$ 4$ in the non-renegotiation region and for a $T=10$-year time horizon of the default probability. The bankruptcy cost, $\alpha$, is $50 \%$; the corporate tax rate, $\tau$, is $15 \%$; the growth rate of earnings, $\mu$, is $1 \%$; the volatility of earnings, $\sigma$, is $25 \%$; the correlation of earnings with the pricing kernel, $\rho$, is $-25 \%$; the volatility of the pricing kernel, $\sigma_{\Lambda}$, is $25 \%$; and the risk-free rate, $r$, is $4 \%$.

shareholder bargaining power $\left(\eta_{i}=0 \%\right)$; the dashed line represents low firmlevel shareholder bargaining power $\left(\eta_{i}=10 \%\right)$; the solid line represents high firm-level shareholder bargaining power $\left(\eta_{i}=20 \%\right) 17$

Observe that shareholders' expected returns are weakly lower after the reform. Even in the special case of high substitutability $\left(\gamma_{i}=1\right)$, firms with a sufficiently low pre-reform bargaining power $\left(\eta_{i}<\eta_{r}\right)$ gain from the reform under this specification. Figure 1 shows that an increased value of the option to default strategically after the BRA decreases stock returns of firms across all levels of default probabilities. This is because equity's option to exchange risky physical assets for safe cash becomes increasingly valuable as the firm's financial health deteriorates. Hence, the adverse consequences for shareholders in case of default are mitigated by the reform, leading to a reduction in equity betas (and hence expected returns) of financially distressed stocks.

Hypothesis 1. For a given default probability, betas and returns should be higher before the reform. The magnitude of this reform effect increases with default probability.

Another important issue is how the reform affects the relationship between firm-level shareholder bargaining power and stock returns of financially distressed firms. Prior to the reform, shareholders of firms with high bargaining power have the ability to extract higher rents in renegotiations with

17 Although the values to the right are empirically less relevant, the figure depicts the full range of default probability. 
creditors. After the reform, shareholders of firms previously equipped with low shareholder bargaining power (low $\eta_{i}$ ) are better protected by the bankruptcy law (i.e, the value of $\eta_{r}$ is larger than the value of $\eta_{i}$ ), especially when the reform is largely complementary (low $\gamma_{i}$ in the second panel of Figure 1). In contrast, this effect is weaker for firms that are equipped with high shareholder bargaining power to begin with (high $\eta_{i}$ ) and benefit relatively less from the reform because the potential gain in bargaining power is more of a substitute for their pre-reform level of bargaining power (high $\gamma_{i}$ in the third panel of Figure 1). For these firms, the effect of firm-level shareholder bargaining power should be more pronounced before the reform when their marginal effects are stronger. Because shareholders of all firms are subject to a minimum level of protection after the reform, the incremental value of more firm-level shareholder bargaining power is lower.

Hypothesis 2. The effect of firm-level shareholder bargaining power interacted with default probability on betas and returns is weaker after the reform.

Finally, we examine the influence of firm-level shareholder bargaining power and reform-based shareholder bargaining power on credit spreads of corporate debt. An increase in shareholder bargaining power creates a wealth transfer from debtholders to equityholders. Therefore, debt values (credit spreads) decrease (increase) monotonically with shareholder bargaining power. Variation in firmlevel shareholder bargaining power also suggests a differential effect for yield spreads.

Hypothesis 3. For a given default probability, credit spreads should be higher after the reform. The magnitude of this reform effect increases with default probability. The effect of firm-level bargaining power of shareholders interacted with default probability on credit spreads is weaker after the reform.

\section{Data Description}

The sample period ranges from January 1975 to December 1984. In out-ofsample tests, we extend it to 2009. Accounting and stock market data are taken from the annual COMPUSTAT, daily and monthly Center for Research in Security Prices (CRSP) databases, and Kenneth French's website. To measure default risk, we use Campbell, Hilscher, and Szilagyi's 2008) hazard model, which estimates the default probability in one year given survival after eleven months by optimizing accounting and market-based explanatory variables applied in similar approaches (see, e.g., Shumway 2001, 18 The parameters

Appendix B provides a brief description of the hazard model and variable definitions. 
Table 5

Default model parameters

\begin{tabular}{lcccrrrrrr} 
& Variable & NIMTA & TLMTA & EXRET & RSIZE & SIGMA & CASHMTA & MB & PRICE \\
\hline Campbell et al. data & Mean & 0.000 & 0.445 & -0.011 & -10.456 & 0.562 & 0.084 & 2.041 & 2.019 \\
& Std. & 0.023 & 0.280 & 0.117 & 1.922 & 0.332 & 0.097 & 1.579 & 0.883 \\
Full sample & Mean & 0.010 & 0.450 & 0.004 & -10.323 & 0.597 & 0.082 & 1.720 & 2.175 \\
& Std. & 0.025 & 0.237 & 0.129 & 1.833 & 0.387 & 0.102 & 1.520 & 0.690 \\
Pre-reform & Mean & 0.012 & 0.468 & 0.009 & -10.297 & 0.604 & 0.076 & 1.644 & 2.198 \\
& Std. & 0.024 & 0.234 & 0.128 & 1.841 & 0.390 & 0.094 & 1.499 & 0.674 \\
Post-reform & Mean & 0.004 & 0.398 & -0.013 & -10.418 & 0.573 & 0.103 & 2.001 & 2.091 \\
& Std. & 0.025 & 0.236 & 0.131 & 1.801 & 0.374 & 0.126 & 1.565 & 0.737 \\
\hline
\end{tabular}

This table reports sample averages and standard deviations for accounting and market-based variables that predict default in the model of Campbell. Hilscher, and Szilagvi 2008). In particular, we reproduce these authors' summary statistics along with our summary statistics for these variables during the full sample period, the pre-reform period, and the post-reform period. Appendix B provides variable definitions. The full sample starts in January 1975 and ends in December 1984, skipping the months from November 1978 to February 1981. The pre-reform sample period is from January 1974 to October 1978; the post-reform sample period ranges from March 1981 to December 1984.

of the model are updated annually starting in 1981, using historically available data to avoid look-ahead bias 19 Because our data analysis starts in 1975, we apply the first available estimates from 1981 to the preceding years. The explanatory variables of the model comprise relative firm size, past return in excess over the market return, net income to the sum of total liabilities and market capitalization, total liabilities to the sum of total liabilities and market capitalization, cash and short-term assets to the sum of total liabilities and market capitalization, the standard deviation of daily stock returns over the past three months, and the market-to-book (M/B) ratio. Accounting variables are based on the prior fiscal year end; the market-based variables are updated every month. For a firm-month observation to be included, information must be available from the annual COMPUSTAT database as well as the daily and monthly CRSP databases. Following standard practice, we exclude financial and utility firms, and stocks with a price below one dollar.

Table 5 summarizes the sample properties of the variables for the default risk measure. It reveals that the descriptive statistics of the model's explanatory variables for our sample period are similar to those reported in Campbell, Hilscher, and Szilagyi (2008). Firms sorted into the same default risk deciles before and after the reform will also be similar in terms of the model's explanatory variables.

In Table 6 we split the sample into (monthly updated) decile portfolios according to their default risk measure, and summarize sample averages of the default measure, portfolio returns, and portfolio characteristics, such as CAPM betas, annualized daily stock return standard deviations, bond spreads, and market-to-book ratios for the pre- and post-reform subsamples. Panel A reveals that the average default measure is not higher for the top quintile portfolio before the reform. Hence, our results are not driven by a decrease in default

19 We are grateful to Jens Hilscher, who provided us with the annually updated parameter estimates for the model. 
Table 6

Descriptive statistics

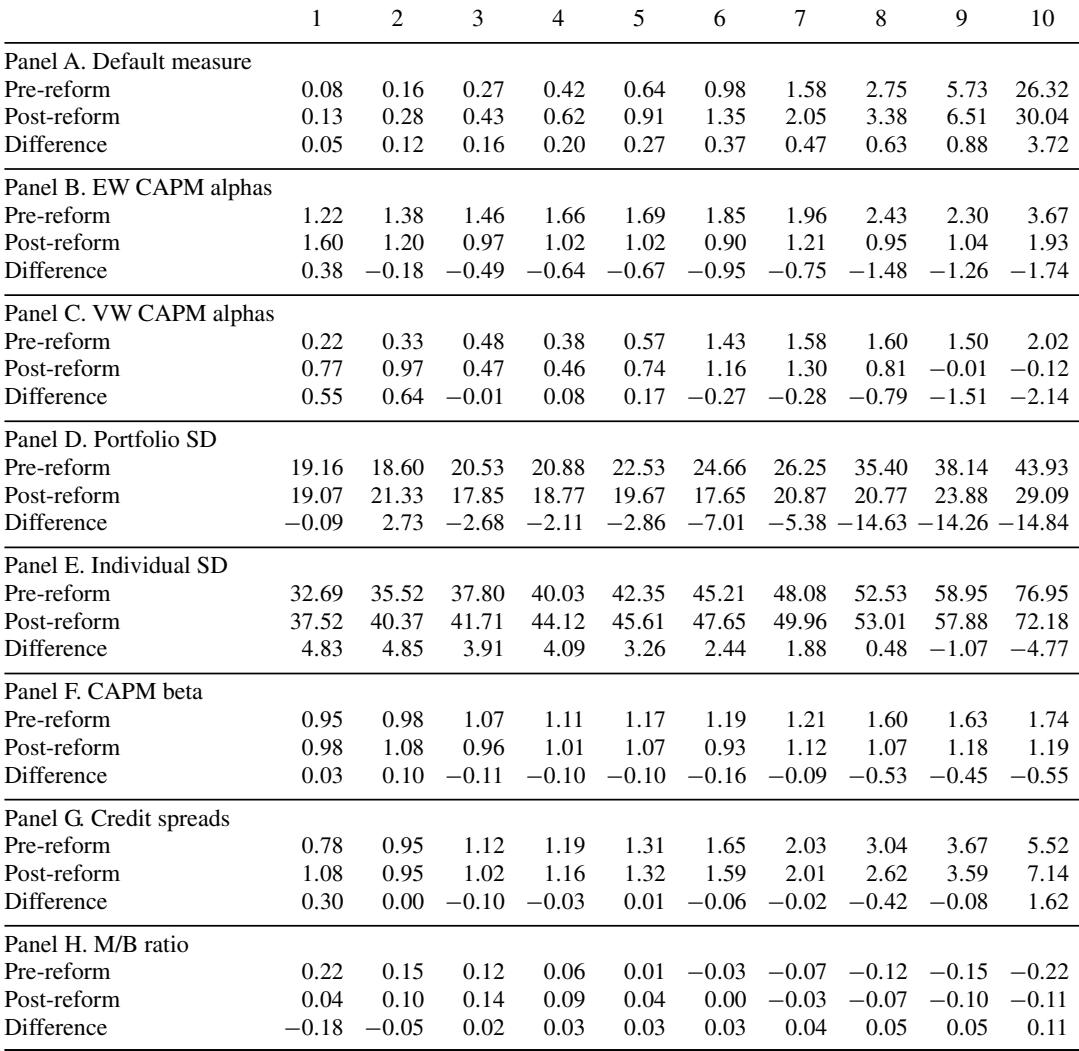

In this table, we split the sample into (monthly updated) portfolios using deciles according to the default risk measure, where 1 stands for the portfolio comprising the least distressed stocks and 10 represents the portfolio containing the most distressed stocks. We calculate portfolio characteristics (averages) for the pre-reform period (January 1975 to October 1978) and the post-reform period (March 1981 to December 1984) for each of the ten portfolios. We skip one month between portfolio formation and computation of portfolio characteristics. We also compute the difference before and after the reform for each of the ten portfolios. Panel A reports average default measures (in basis points). Panels B and C show, respectively, average equal-weighted and value-weighted alphas of monthly portfolio returns regressed on the market premium (percentage points) per month. Panels D and $\mathrm{E}$ tabulate annualized standard deviations of daily value-weighted portfolio returns and average individual firm returns. Panel F summarizes CAPM betas for value-weighted portfolios, Panel G shows average corporate bond credit spreads, and Panel $\mathrm{H}$ depicts market-to-book ratios adjusted for industry-month averages.

risk after the passing of the BRA. We discuss the implications of the pre- and post-reform portfolio characteristics in Section 4.1

We obtain data on inside ownership from the Forbes Executive Compensation Survey. It contains stock ownership of management in million dollars. We divide this quantity by the number of shares outstanding times the share price from COMPUSTAT to obtain a measure of management ownership. As there is no survey from 1975 to 1985 , we take the average ownership share from 1974 and 1986 to proxy for management ownership during this period. 
Corporate bond yields come from the Lehman Brothers Fixed Income Database. We match the bond data to the sample by six-digit CUSIP numbers. To avoid mis-matching, we manually verify each match. To compute credit spreads, we take the difference between the corporate bond yield and the Treasury yield of the same maturity, available from the Federal Reserve Economic Database. We construct the entire yield curve using linear interpolation of one-, two-, three-, five-, seven-, ten-, twenty-, and thirty-year Treasuries. If a firm has several bonds outstanding per month, we compute the value-weighted average of the bond spreads for each firm-month observation. For a small sample of firms we collect data on actual occurrences of APR violations in bankruptcy proceedings. We construct a data set from three empirical studies on deviations from absolute priority (i.e., Franks and Torous 1989; Eberhart, Moore, and Roenfeld 1990; Weiss 1990) and examine those firms' stock returns 20

\section{Empirical Analysis}

This section outlines the empirical strategy employed in this paper to test the hypotheses from the strategic default model and reports the paper's main results.

\subsection{Changes in returns, betas, and valuations}

Due to higher concessions to shareholders in bankruptcy proceedings, we expect that risk premia for shareholders in distressed firms should be lower after the BRA (Hypothesis 1). To test for changes in equity risk premia of distressed firms, we sort stocks according to the default risk measure every month. We skip one month between portfolio formation and computation of portfolio returns. We apply standard factor models to calculate abnormal portfolio returns (alphas) and risk factor loadings using data on the factor-mimicking portfolios from Kenneth French's data library. To rule out concerns that other confounding shocks affect returns and risk premia of stocks, we compute monthly alphas and betas of a long-short portfolio investing in the riskiest stocks and selling the safest stocks. This long-short portfolio approach eliminates the effects of shocks that affect distressed and safe stocks equally.

We begin with a graphical analysis of portfolio returns. Figure 2 plots cumulated monthly equal-weighted returns of the long-short portfolio buying stocks in the top quintile of the default risk measure and selling stocks in the lowest quintile in Panel A. The vertical line represents the passing of the BRA in November 1978. The dashed line charts unadjusted returns, and the solid line charts returns adjusted for market, size, book-to-market, and momentum factors. The graph provides evidence of a distinct change in default risk pricing around the passing of the BRA.

20 For some firms, both Franks and Torous 1989) and Eberhart, Moore, and Roenfeld (1990) report APR violations. In these cases, we use the estimates of Franks and Torous The results are qualitatively identical when we use the Eberhart, Moore, and Roenfeld 1990) values. 

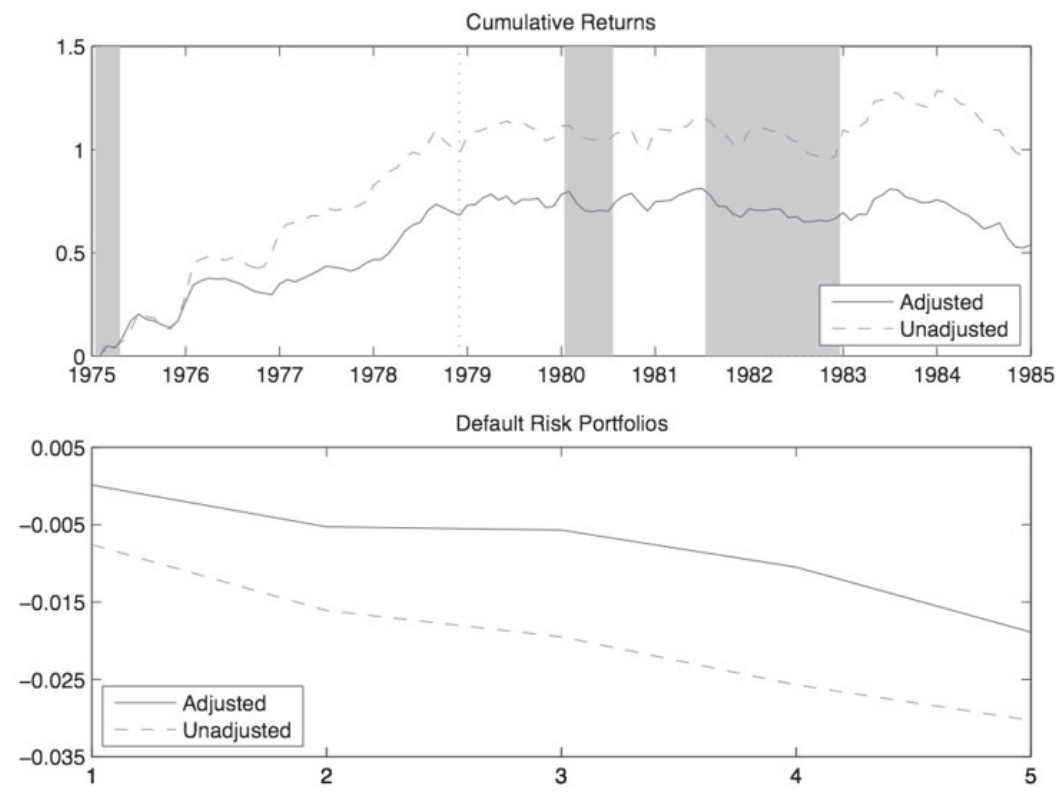

Figure 2

\section{Cumulative portfolio returns}

This figure plots cumulative returns of the equal weighted long-short portfolio buying stocks in the top quintile of default risk and selling stocks in the bottom quintile in Panel A. The dashed lines chart unadjusted returns, and the solid lines chart returns adjusted for market, size, book-to-market, and momentum factors. The gray, shaded areas indicate recession periods during our sample period according to the NBER classifications. The dotted, vertical line marks the passing of the Bankruptcy Reform Act in November 1978. Panel B shows the reduction in quintile portfolio returns for different default risks $(1=$ Low, $5=$ High $)$ due to the BRA (i.e., post- minus pre-reform average monthly portfolio returns) on the y axis.

In the 46-month period before the BRA, the abnormal return of the highest risk quintile in excess of the lowest risk quintile portfolio accumulates to $70 \%$ for adjusted and $101 \%$ for unadjusted returns. In the 46-month period after skipping the period from March 1981 to December 1984, the cumulative excess return is negative, with $-22 \%$ for adjusted and $-10 \%$ for unadjusted returns. The change in distress risk premia is persistent during the entire period and not driven by the impact of recessions (gray, shaded areas). Thus, the results provide evidence of a stable trend in risk premia instead of being driven by a short period of extreme returns. Panel B displays the magnitude of the reduction in returns due to the BRA for portfolios split according to the default risk measure. The return on the highest risk quintile is reduced by $-3.03 \%$ per month for unadjusted and $-1.89 \%$ for adjusted returns. For the lowest risk quintile, the return slightly decreases by $-0.76 \%$ for unadjusted and increases by $0.01 \%$ for adjusted returns. This suggests that the effect of the reform is strong for distressed firms but marginal for safe firms. The reform effect is clearly monotonic, with a slightly steeper slope at the high end of the default risk distribution, indicating that the reform has the strongest impact on highly 
distressed stocks. The empirical evidence from Panel B in Figure 2 is consistent with the theoretical predictions from Figure 1] When we take the difference between expected returns in the post-reform period (Plot 2 or 3) and the prereform period (Plot 1), we obtain the same monotonic increase in the reform's effect on expected returns with firms' default risk.

To statistically confirm the insights from the graphical analysis, we apply the factor models separately to the periods before and after the BRA. The results are summarized in Models 1-3 in Table 7 Panel A shows the results for the period before the BRA (January 1975 to October 1978), Panel B shows the results for the period after the BRA (March 1981 to December 1984). Panel C displays the coefficients for alphas and betas interacted with a reform dummy that takes the value of one in the post-reform and zero in the pre-reform period. The coefficients can be interpreted as changes in alphas and betas of the long-short portfolio in the post-reform compared with the pre-reform period.

We regress the monthly portfolio return on a constant (Model 1), a market model (Model 2), and the four-factor Carhart 1997) model with market, size, book-to-market, and momentum factors (Model 3). All models show a significant reduction in alphas after the BRA. The magnitude ranges from $2.51 \%$ when we regress the portfolio returns on a constant (Model 1), $-2.10 \%$ for the CAPM (Model 2), to $-0.86 \%$ in the case of the four-factor model (Model 3 ). The effect is economically and statistically significant in all specifications. Thus, even after controlling for common risk factors, there is still a significant reduction in alphas after the BRA. This suggests that distress risk is not spanned by the market factor or the market, value, size, and momentum factors. The reduction in the effect on alpha in the four-factor model, compared with the raw returns or the CAPM, is in line with the literature that links the value and size factors to distress risk (e.g., Chan and Chen 1991). The loadings of the portfolio on the value and size factors drop significantly after the BRA. This is consistent with distressed firms being less exposed to distress risk, and value and size factors being correlated with distress risk. We interpret these results as evidence for a reduction in the share of distress risk borne and hence priced by shareholders of distressed firms due to the BRA.

In Models 4-8 we switch from portfolio-level to firm-level analysis. For Models 4-6, for each firm we estimate one alpha and beta for the different models for the pre-reform and post-reform periods separately. Then we run cross-sectional regressions of those firm-level alphas and betas on firms' average default risk during the period. For the default risk variable, we split the stocks into quintiles according to their risk measure each month. The default risk variable ranges from 1 for the safest stocks to 5 for the riskiest stocks 21

21 An online appendix available at http://ssrn.com/abstract=2517596 or by request from the authors, shows that the results in Table 7 are robust to controlling for recessionary periods, annual portfolio updating, value-weighted portfolios, and industry effects. In further robustness tests, we replicate all tests of alphas, betas, and valuations in Models 4-8 in Table 7 using the log of the default risk measure instead of default quintiles to account for the possibility of changes in default risk. The results are qualitatively identical to those with default risk quintiles. 
Table 7

Reform effect

Model $1 \quad$ Model $2 \quad$ Model $3 \quad$ Model 4 Model $5 \quad$ Model 6 Model $7 \quad$ Model 8

\begin{tabular}{|c|c|c|c|c|c|c|c|c|}
\hline \\
\hline & & & & & & & & \\
\hline \multicolumn{9}{|l|}{$\begin{array}{l}\text { Panel A. Pre-reform } \\
\text { Alpha }\end{array}$} \\
\hline$t$-statistic & {$[2.90]$} & {$[2.55]$} & {$[1.50]$} & {$[6.74]$} & {$[5.72]$} & [3.93] & & \\
\hline Market beta & & $0.47^{* *}$ & 0.04 & & $0.06^{* * *}$ & $-0.02^{*}$ & & \\
\hline$t$-statistic & & {$[2.54]$} & {$[0.53]$} & & {$[5.61]$} & [1.80] & & \\
\hline Value beta & & & $0.93^{* * *}$ & & & $0.16^{* * *}$ & & \\
\hline$t$-statistic & & & {$[6.75]$} & & & {$[7.60]$} & & \\
\hline Size beta & & & $1.20^{* * *}$ & & & $0.32^{* * *}$ & & \\
\hline$t$-statistic & & & {$[9.76]$} & & & {$[16.16]$} & & \\
\hline Momentum beta & & & $-0.70^{* * *}$ & & & $-0.04^{* *}$ & & \\
\hline$t$-statistic & & & [6.58] & & & [1.99] & & \\
\hline $\mathrm{M} / \mathrm{B}$ ratio & & & & & & & $-0.18^{* * *}$ & \\
\hline$t$-statistic & & & & & & & {$[15.33]$} & \\
\hline Std(ret) & & & & & & & & $7.70^{* * *}$ \\
\hline$t$-statistic & & & & & & & & {$[21.00]$} \\
\hline Observations & 46 & 46 & 46 & 3673 & 3673 & 3673 & 143689 & 145784 \\
\hline \multicolumn{9}{|l|}{ Panel B. Post-reform } \\
\hline Alpha & 0.08 & 0.09 & -0.35 & $-0.26^{* * *}$ & $-0.22^{* * *}$ & $-0.36^{* * *}$ & & \\
\hline$t$-statistic & {$[0.18]$} & {$[0.20]$} & {$[0.83]$} & [5.67] & [4.77] & [6.34] & & \\
\hline Market beta & & -0.08 & -0.12 & & $-0.02^{*}$ & $-0.04^{* *}$ & & \\
\hline$t$-statistic & & {$[0.83]$} & {$[1.13]$} & & {$[1.74]$} & [2.29] & & \\
\hline Value beta & & & $0.36^{* *}$ & & & $0.08^{* * *}$ & & \\
\hline$t$-statistic & & & {$[2.21]$} & & & [3.87] & & \\
\hline Size beta & & & $0.75^{* * *}$ & & & $0.17^{* * *}$ & & \\
\hline$t$-statistic & & & [5.09] & & & [5.87] & & \\
\hline Momentum beta & & & $-0.51^{* * *}$ & & & $-0.07^{* * *}$ & & \\
\hline$t$-statistic & & & [3.95] & & & {$[3.25]$} & & \\
\hline $\mathrm{M} / \mathrm{B}$ ratio & & & & & & & $-0.12^{* * *}$ & \\
\hline$t$-statistic & & & & & & & {$[5.06]$} & \\
\hline Std(ret) & & & & & & & & $5.63^{* * *}$ \\
\hline$t$-statistic & & & & & & & & {$[17.76]$} \\
\hline Observations & 46 & 46 & 46 & 4594 & 4594 & 4594 & 150693 & 162269 \\
\hline \multicolumn{9}{|l|}{ Panel C. Reform effect } \\
\hline Alpha & $-2.51^{* *}$ & $-2.10^{* *}$ & $-0.86^{*}$ & $-0.52^{* * *}$ & $-0.43^{* * *}$ & $-0.20^{* * *}$ & & \\
\hline$t$-statistic & [2.53] & [2.19] & [1.69] & [8.43] & [7.03] & [2.64] & & \\
\hline Market beta & & $-0.55^{* *}$ & -0.16 & & $-0.08^{* * *}$ & -0.01 & & \\
\hline$t$-statistic & & [2.59] & [1.22] & & [4.98] & {$[0.66]$} & & \\
\hline Value beta & & & $-0.57^{* * *}$ & & & $-0.08^{* *}$ & & \\
\hline$t$-statistic & & & {$[2.65]$} & & & {$[2.57]$} & & \\
\hline Size beta & & & $-0.44^{* *}$ & & & $-0.15^{* * *}$ & & \\
\hline$t$-statistic & & & [2.29] & & & [4.01] & & \\
\hline Momentum beta & & & 0.20 & & & 0.03 & & \\
\hline$t$-statistic & & & [1.19] & & & [0.93] & & \\
\hline $\mathrm{M} / \mathrm{B}$ ratio & & & & & & & $0.05^{* *}$ & \\
\hline$t$-statistic & & & & & & & {$[2.04]$} & \\
\hline Std(ret) & & & & & & & & $-2.07 * * *$ \\
\hline$t$-statistic & & & & & & & & [4.45] \\
\hline Observations & 92 & 92 & 92 & 8267 & 8267 & 8267 & 294382 & 308053 \\
\hline
\end{tabular}

For the results in Models 1-3, we sort stocks into quintiles according to their default measure and construct a long-short portfolio investing in the riskiest $20 \%$ and going short in the safest $20 \%$ of stocks. We skip one month between monthly portfolio formation and portfolio returns. We show the results from the regression of monthly equal-weighted returns over the risk-free rate on a constant (Model 1), a market factor (Model 2), and the Carhart 1997 four-factor model (Model 3). For the results in Models 4-6, we estimate alphas and betas for the prereform and post-reform periods separately for each firm by regressing returns over the risk-free rate on a constant (Model 4), a market factor (Model 5), and a four-factor model (Model 6). We compute the average of each firm's default measure quintile separately for both periods and then run cross-sectional regressions separately for firm-level alphas and betas on firms' average default rank. We run monthly regressions of industry-adjusted market-to-book ratios in Model 7 and annualized stock return volatility (estimated from daily returns) in Model 8 on firms' monthly updated default rank including month fixed effects. Standard errors in Models 7 and 8 control for clustering at the firm and month levels. Results for the pre-reform period from January 1975 to October 1978 are in Panel A, and the results from the post-reform period from March 1981 to December 1984 in Panel B. Panel C displays the differences between the post-reform and pre-reform period estimates. * indicates statistical significance at the $10 \%$ level, $* *$ at the $5 \%$ level, and $* * *$ at the $1 \%$ level. 
If shareholders of distressed firms have higher bargaining power after the BRA, higher shareholder recovery also implies higher valuations. We test for differences in valuation by comparing industry-month adjusted, monthlycomputed market-to-book ratios for distressed relative to safe firms before and after the BRA. Model 7 in Table 7 shows that, while M/B ratios of distressed firms are lower than those of safer firms before and after the reform, there is a significant relative increase in $\mathrm{M} / \mathrm{B}$ ratios by 0.05 per default risk quintile after the reform (Panel C). In Model 8, we test whether the descriptive statistics documented in Panel E of Table 6 are statistically significant by regressing monthly observations of individual stocks' annualized equity volatility computed from daily stock returns as the dependent variable on the default risk variable. Stock return volatility of distressed firms significantly declines relative to safe firms after the reform.

The descriptive statistics in Table 6 are in line with our main results and verify that what we observe is a pricing effect and not a result of investors being surprised by low stock returns. While the average default measure of the riskiest $20 \%$ of firms is not lower after the reform (Panel A), the riskiness of these stocks decreases as indicated by reductions of individual and portfolio return volatilities (Panels D and E), and lower CAPM betas (Panel F). Panel $\mathrm{H}$ documents higher valuations (M/B ratios adjusted for industrymonth fixed effects) of distressed firms after the reform. While there is no general reduction of distress risk for the most distressed firms after the reform, risk exposure for shareholders is reduced through the increase in shareholder recovery. Importantly, those changes are present only in distressed firms, whereas the safest firms exhibit no or only mild changes in market betas, returns, volatilities, and valuations after the reform. This evidence is even more striking in combination with the increase of credit spreads for distressed firms relative to safe firms after the reform (Panel G), suggesting a shift in distress risk borne from debtors to creditors.

\subsection{Cross-sectional heterogeneity in shareholder bargaining power}

The time-series comparison of alphas and betas of distressed relative to safe firms assumes that no unrelated shocks affecting distressed stocks differently from safe stocks coincide with the passing of the BRA. To mitigate concerns that confounding shocks might bias the analysis, we exploit cross-sectional heterogeneity in firm-level shareholder bargaining power. The BRA should have a differential effect on firms with different levels of shareholder bargaining power (Hypothesis 2); other shocks that affect distressed stocks but are not related to cross-sectional differences in shareholder bargaining power should not affect stocks with different levels of shareholder bargaining power differently.

We use four measures to classify firms according to their firm-level degree of shareholder bargaining power. First, it tends to be easier and more profitable for creditors to liquidate firms with more tangible assets. High tangibility 
thus decreases shareholder bargaining power Bergman and Callen 1991 as it reduces creditors' incentives to renegotiate debt to avoid liquidation. We define tangibility as plant, property, and equipment scaled by total assets. Second, a higher level of inside ownership increases the bargaining power of shareholders in Chapter 11 as it further aligns the incentives of management and shareholders Alderson and Betken 1996; Acharya, Bharath, and Srinivasan 2007; Davydenko and Strebulaev 2007). We define inside ownership as the share of stocks held by a firm's top executives. Third, APR deviations are more common for large firms Weiss 1990; Franks and Torous 1994) since the bankruptcy cases are more complicated and tend to have more dispersed debt, and public bond ownership with atomistic bondholders. The coordination of creditors' interests is complex compared with concentrated lenders in small firms reducing creditors' bargaining power. We define firm size as the log of total book assets since market capitalization of distressed firms is often artificially low, and does not reliably reflect creditor structure. Finally, we use R\&D intensity to proxy for shareholder bargaining power as distressed firms with a high R\&D ratio display a lower ability to withstand liquidity shortages Opler and Titman 1994). Additionally, firms with high R\&D expenses are likely to have more intangible investment opportunities that shareholders forego when financing is not provided Lyandres and Zhdanov 2013). These firms' urgent need for liquidity weakens their bargaining power vis-à-vis creditors. We define $R \& D$ intensity as $R \& D$ expenditures scaled by total assets.

We test for heterogeneity in the BRA's effect on different firms by regressing firm-level CAPM betas (estimated separately for the pre-reform and postreform periods) on the default risk measure, bargaining power proxies, and an interaction of the two. We initially run separate cross-sectional regression for the pre-reform and post-reform periods 22

$$
\begin{aligned}
\text { CAPM beta }_{i}= & \alpha+\gamma \cdot \text { control }_{i}+\beta_{1} \cdot \text { default }_{i}+\beta_{2} \cdot \text { BP } \text { proxy }_{i} \\
& +\beta_{3} \cdot \text { default }_{i} * \text { BP } \text { proxy }_{i}+\epsilon_{i}
\end{aligned}
$$

where CAPM beta b $_{i}$ is firm $i$ 's coefficient from regressing monthly returns over the risk-free rate on a constant and the market premium in the respective period. Control variables include the average log of total assets, book-to-market ratio, leverage, and equity volatility over the last three months. We follow Cohen, Polk, and Vuolteenaho 2003) to compute the book value of equity. For the default $_{i}$ variable and the BP proxy $_{i} \in\left\{\operatorname{tang}_{i}\right.$, owner $_{i}, \log \left(\right.$ at $\left._{i}, \operatorname{xrd}_{i}\right\}$ variables, we independently split the sample into deciles according to the firms' average default measure, asset tangibility ratio, inside ownership, size,

22 We thank an anonymous referee for suggesting market betas as a more direct way of testing our hypotheses. In an earlier draft, we find similar results for returns. 
and $R \& D$ intensity for the respective period. We interpret a stronger effect of shareholder bargaining power before the reform, when shareholders are less protected by the bankruptcy code, as a confirmation that a change in bargaining power is what drives the change in distress risk following the BRA. To verify that the differences across periods are statistically significant, we interact the independent variables with a reform dummy, which takes the value of one for the post-reform period and zero otherwise, and estimate Equation 110 for the full sample period.

Table 8 shows the results. Panel A shows the results for the pre-reform period. Before the reform the interaction terms between the shareholder bargaining power proxies and default risk exhibit the expected signs. The betas of distressed stocks are higher for firms in which shareholders have lower bargaining power - firms with a higher level of tangible assets (Model 1), lower inside ownership (Model 2), smaller firms (Model 3), and firms with a higher R\&D ratio (Model 4). In the post-reform period, the effect of firm-level bargaining power proxies on betas is substantially lower (Panel B). The estimates in Panel C show that for three of the proxies the cross-sectional heterogeneity in distress risk premia for firms with different levels of firm-level shareholder bargaining power is significantly lower after the reform (only for size is the difference statistically weaker). This confirms that shareholders in firms with previously lower bargaining power vis-à-vis creditors benefit relatively more from the increase in bargaining power induced by the BRA. Thus, confounding events that coincide with the timing of the reform must explain not only a reduction in distress risk premia, but also a differential effect of firm-level shareholder bargaining power on betas. The results in Table 8 suggest that tangibility and inside ownership are the most direct (or useful) proxies for shareholder bargaining power. For the size proxy, the reform effect is not statistically different, and for the R\&D proxy, the loading is significantly negative after the reform, suggesting that $R \& D$ intensity also proxies for other risk-related firm characteristics.

\subsection{Changes in credit spreads}

To differentiate between an increase in shareholder bargaining power at the expense of creditors and a general decline in risk premia, we examine corporate bond credit spreads. If our findings are driven by an increase in shareholder bargaining power, bondholders' position in distress deteriorates, which should translate into higher credit spreads for riskier firms after the reform.

We analyze changes in credit spreads due to the BRA via Fama and MacBeth 1973 ) regressions of corporate bond over Treasury bond yields with the same maturity on default deciles. Following Davydenko and Strebulaev 2007), we control for measures of non-strategic default risk to isolate the strategic default channel: the log of total assets, equity volatility over the last three months, firm leverage, the coupon rate, and the time to maturity of the bond. As for 
Table 8

Shareholder bargaining power and market betas

\begin{tabular}{|c|c|c|c|c|}
\hline \multicolumn{5}{|l|}{ 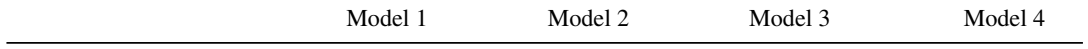 } \\
\hline $\begin{array}{l}\text { Panel A: Pre-reform } \\
\text { default }\end{array}$ & $\begin{array}{c}-0.0125 \\
{[0.92]}\end{array}$ & $\begin{array}{l}-0.0464^{* *} \\
{[2.23]}\end{array}$ & $\begin{array}{l}-0.0621^{* * *} \\
{[4.65]}\end{array}$ & $\begin{array}{l}-0.0448^{* * *} \\
{[2.81]}\end{array}$ \\
\hline default*tang & $\begin{array}{l}0.0102^{* *} \\
{[2.52]}\end{array}$ & & & \\
\hline default*owner & & $\begin{array}{c}-0.0034 \\
{[1.47]}\end{array}$ & & \\
\hline default* $\log ($ at $)$ & & & $\begin{array}{l}-0.1794^{* *} \\
{[2.13]}\end{array}$ & \\
\hline default*xrd & & & & $\begin{array}{l}0.0068^{* * *} \\
{[3.23]}\end{array}$ \\
\hline Observations & 3604 & 595 & 3605 & 2200 \\
\hline$R^{2}$ & 0.046 & 0.225 & 0.074 & 0.148 \\
\hline $\begin{array}{l}\text { Panel B: Post-reform } \\
\text { default }\end{array}$ & $\begin{array}{l}-0.0312^{* * *} \\
{[3.16]}\end{array}$ & $\begin{array}{c}-0.0132 \\
{[0.69]}\end{array}$ & $\begin{array}{l}-0.0650^{* * *} \\
{[6.05]}\end{array}$ & $\begin{array}{c}-0.0038 \\
{[0.26]}\end{array}$ \\
\hline default*tang & $\begin{array}{l}0.0024 \\
{[1.56]}\end{array}$ & & & \\
\hline default*owner & & $\begin{array}{l}0.0032 \\
{[1.32]}\end{array}$ & & \\
\hline default* $\log ($ at $)$ & & & $\begin{array}{c}-0.0258 \\
{[0.32]}\end{array}$ & \\
\hline default*xrd & & & & $\begin{array}{l}-0.0052^{* *} \\
{[2.12]}\end{array}$ \\
\hline Observations & 4381 & 552 & 4382 & 2438 \\
\hline$R^{2}$ & 0.038 & 0.069 & 0.056 & 0.097 \\
\hline $\begin{array}{l}\text { Panel C: Reform effect } \\
\text { default }\end{array}$ & $\begin{array}{c}-0.0187 \\
{[1.10]}\end{array}$ & $\begin{array}{l}0.0349 \\
{[1.23]}\end{array}$ & $\begin{array}{c}-0.0029 \\
{[0.17]}\end{array}$ & $\begin{array}{l}0.0362^{*} \\
{[1.67]}\end{array}$ \\
\hline default*tang & $\begin{array}{c}-0.0075^{*} \\
{[1.72]}\end{array}$ & & & \\
\hline default*owner & & $\begin{array}{l}0.0065^{*} \\
{[1.96]}\end{array}$ & & \\
\hline default* $\log ($ at $)$ & & & $\begin{array}{l}0.1537 \\
{[1.32]}\end{array}$ & \\
\hline default*xrd & & & & $\begin{array}{l}-0.0120^{* * *} \\
{[3.71]}\end{array}$ \\
\hline Observations & 7985 & 1147 & 7987 & 4638 \\
\hline$R^{2}$ & 0.074 & 0.188 & 0.086 & 0.130 \\
\hline
\end{tabular}

For the results in this table, for each firm we estimate CAPM betas for the pre-reform period from January 1975 to October 1978 (Panel A) and the post-reform period from March 1981 to December 1984 (Panel B) by regressing firms' excess returns over the risk-free rate on the market premium. Each month, we separately sort firms into deciles according to their default measure and their bargaining power proxies: size defined as logarithm of total book assets $(\log (a t))$; $\mathrm{R} \& \mathrm{D}$ ratio defined as $\mathrm{R} \& \mathrm{D}$ expenditures by total assets $(x r d)$; tangibility ratio defined as property, plant, and equipment scaled by total assets (tang); and inside ownership share defined as management stock holdings divided by total stocks outstanding (owner). We then run cross-sectional regressions of the firm-level betas on firms' average default rank, the average rank of their shareholder bargaining power proxy, and the interaction between the two. For the estimates in Panel $\mathrm{C}$ we add a reform dummy that is one for the post-reform period, and zero for the pre-reform period, and the interaction of the reform dummy with the other variables. The estimates presented in Panel $\mathrm{C}$ are the interaction of the reform dummy with the average default rank and average bargaining power proxy rank. Each estimation contains as control variables: the average log of firms' book-to-market ratio, average monthly return volatility, and average leverage ratio for the pre-reform and post-reform periods. * indicates statistical significance at the $10 \%$ level, ** at the $5 \%$ level, and *** at the $1 \%$ level.

equity betas, we expect that before the reform, when cross-sectional differences in bargaining power are more pronounced, firm-level shareholder bargaining power proxies should have a significant impact on risk premia for distressed 


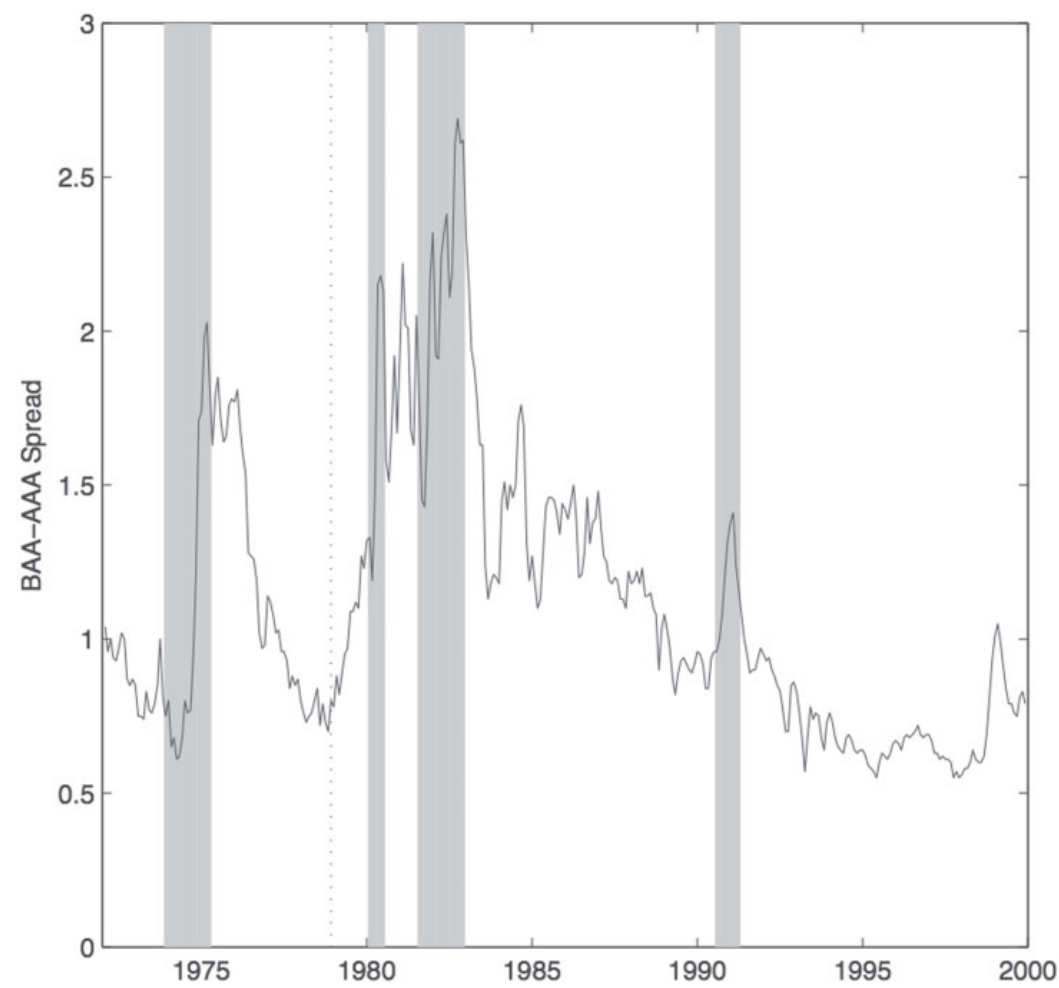

Figure 3

BAA-AAA corporate bond credit spread

This figure depicts the percentage point spread of Baa- over Aaa-rated Moody's seasoned corporate bonds reported on the y axis for the time-series from 1972 to 2000. The gray-shaded areas mark recession periods according to the NBER classifications. The dotted, vertical line marks the passing of the Bankruptcy Reform Act in November 1978.

firms' bonds in the cross-section. After the reform, when shareholders in all firms have more bargaining power, we expect higher risk premia for creditors and a weakened effect of bargaining power proxies in explaining cross-sectional differences in credit spreads (Hypothesis 3).

We start the analysis of credit spreads by plotting the time series of the Moody's BAA-AAA spread (Figure 3). We observe an increase in the BAAAAA spread after the reform, consistent with the findings on small business loan pricing by banks after the BRA in Scott and Smith 1986). The evolution of the BAA-AAA spread is inconsistent with a parallel movement of risk premia for bonds and stocks of distressed firms. The increase of the BAA-AAA spread supports the view that bondholders demand a higher rate of return for risky firms as a consequence of the shift in bargaining power induced by the BRA. Thus, while the period after the passing of the BRA exhibits lower distress risk premia on stocks, corporate bond credit spreads are higher. 
Table 9

Shareholder bargaining power and credit spreads

\begin{tabular}{|c|c|c|c|c|c|c|}
\hline & Model 1 & Model 2 & Model 3 & Model 4 & Model 5 & Model 6 \\
\hline $\begin{array}{l}\text { Panel A: Pre-reform } \\
\text { default }\end{array}$ & $\begin{array}{l}0.62^{* * *} \\
{[34.52]}\end{array}$ & $\begin{array}{c}0.03 \\
{[1.34]}\end{array}$ & & & & \\
\hline def*tang & & & $\begin{array}{l}-0.03^{* * *} \\
{[7.50]}\end{array}$ & & & \\
\hline def*owner & & & & $\begin{array}{l}0.04^{* * * *} \\
{[8.09]}\end{array}$ & & \\
\hline def* $\log (\mathrm{at})$ & & & & & $\begin{array}{c}0.02^{*} \\
{[1.90]}\end{array}$ & \\
\hline def*xrd & & & & & & $\begin{array}{l}-0.01 * * * \\
{[3.73]}\end{array}$ \\
\hline Controls & no & yes & yes & yes & yes & yes \\
\hline Observations & 11,154 & 11,154 & 11,154 & 7,484 & 11,154 & 7,653 \\
\hline$R^{2}$ & 0.197 & 0.495 & 0.455 & 0.552 & 0.484 & 0.589 \\
\hline $\begin{array}{l}\text { Panel B: Post-reform } \\
\text { default }\end{array}$ & $\begin{array}{l}0.81^{* * *} \\
{[18.96]}\end{array}$ & $\begin{array}{l}0.13^{* * *} \\
{[3.29]}\end{array}$ & & & & \\
\hline def*tang & & & $\begin{array}{c}0.01 \\
{[0.65]}\end{array}$ & & & \\
\hline def*owner & & & & $\begin{array}{c}-0.01 \\
{[0.56]}\end{array}$ & & \\
\hline def*log(at) & & & & & $\begin{array}{l}-0.09^{* * *} \\
{[6.66]}\end{array}$ & \\
\hline def*xrd & & & & & & $\begin{array}{c}0.00 \\
{[0.56]}\end{array}$ \\
\hline Controls & no & yes & yes & yes & yes & yes \\
\hline Observations & 10,281 & 10,281 & 10,281 & 6,230 & 10,281 & 6,288 \\
\hline$R^{2}$ & 0.215 & 0.487 & 0.504 & 0.627 & 0.651 & 0.644 \\
\hline $\begin{array}{l}\text { Panel C: Reform effect } \\
\text { default }\end{array}$ & $\begin{array}{l}0.19^{* * *} \\
{[4.10]}\end{array}$ & $\begin{array}{c}0.09 * \\
{[1.95]}\end{array}$ & & & & \\
\hline def*tang & & & $\begin{array}{l}0.04^{* *} \\
{[2.17]}\end{array}$ & & & \\
\hline def*owner & & & & $\begin{array}{c}-0.04^{* * *} \\
{[4.00]}\end{array}$ & & \\
\hline def* $\log (a t)$ & & & & & $\begin{array}{c}-0.11^{* * *} \\
{[6.39]}\end{array}$ & \\
\hline def*xrd & & & & & & $\begin{array}{r}0.01^{*} \\
{[1.73]}\end{array}$ \\
\hline
\end{tabular}

In this table the regression results in Panel A span the pre-reform period from January 1975 to October 1978, the regressions in Panel B cover the period from March 1981 to December 1984. The dependent variable is the credit spread in basis points relative to Treasury bonds with the same maturity. Each month, we separately sort firms into deciles according to their default measure and their bargaining power proxies: size defined as logarithm of total book assets $(\log (a t))$; R\&D ratio defined as R\&D expenditures divided by total assets $(x r d)$; tangibility ratio defined as property, plant, and equipment scaled by total assets (tang); and inside ownership share defined as management stock holdings divided by total stocks outstanding (owner). We run Fama and MacBeth 1973) regression analysis with Newey and Wes 1987), adjusted standard errors by month on firms' default rank, shareholder bargaining power proxy rank, and the interaction between the two. Panel $\mathrm{C}$ reports the difference in the interaction between the default measure and the bargaining power proxy ranks for the post-reform compared with the pre-reform period. The estimations in Models 2-6 contain as control variables: the log of firms' assets, equity volatility over the previous three months, leverage, the coupon rate, and the time to maturity of the bond. $*$ indicates statistical significance at the $10 \%$ level, $* *$ at the $5 \%$ level, and *** at the $1 \%$ level.

The results for cross-sectional differences in credit spreads are summarized in Table 9 Model 1 shows that bondholders charge significantly higher credit spreads for distressed firms after the BRA with 81 basis points per risk decile (Panel B), as opposed to 62 basis points in the pre-reform period (Panel A). 
Controlling for non-strategic variables (firm size, leverage, equity volatility) and bond characteristics (coupon rate, maturity) in Model 2, the credit spread per default risk decile decreases to 3 basis points before the reform, but remains statistically significant with 13 basis points after the BRA. We also find a differential effect in that credit spreads vary with firm-level shareholder bargaining power more before than they do after the reform. Models 3-6 in Panel A reveal that credit spreads are higher for firms with higher shareholder bargaining power before the reform (low tangibility, high inside ownership, large firms, or low R\&D intensity firms). Models 3-6 in Panel B show that the increase in reform-based shareholder bargaining power reduces cross-sectional differences in credit spreads across firms with different degrees of firm-level shareholder bargaining power. Finally, the estimates in Panel C confirm that the reduction in the effect of firm-level shareholder bargaining power in the crosssection is statistically significant for all bargaining power proxies. Overall, these results strongly support the interpretation of the earlier findings. Credit spreads increase when distress risk premia for shareholders decrease, and in particular, credit spreads rise more for those firms with a larger decline in distress risk premia for shareholders.

\section{Supporting Evidence}

In this section, we provide supporting evidence for our main findings. First, we test how equity premia change when some of the effects on shareholder bargaining power from the BRA are reversed in the early 1990s (out-ofsample tests). Second, for a hand-collected sample of firms, we find a negative relationship between actual APR violations and equity premia.

\subsection{Out-of-sample tests}

The emergence of debtor-in-possession (DIP) financing in the early 1990s changed the distribution of bargaining power in bankruptcy in favor of creditors 23 Under DIP financing, creditors that provide loans to firms in Chapter 11 proceedings are placed right below or even at the same level as existing secured creditors in the priority structure. DIP financing typically imposes explicit governance conditions and precise requirements for the debtor to comply with (see, e.g., Skee 2003) on sale of specific assets and liquidation in cases where prespecified levels of profits are not generated). In addition to DIP financing, key employee retention plans (KERPs) started to emerge in the 1990s. These plans enabled creditors to better align management's

23 See, e.g., Skeel 2003), Ayotte and Morrison 2009), and Bharath, Panchapegesan, and Wernet 2010). "The endless negotiations and mind-numbingly bureaucratic process that seemed to characterize bankruptcy in the 1980s have been replaced.... Whereas the debtor and its managers seemed to dominate bankruptcy only a few years ago, Chapter 11 now has a distinctively creditor-oriented cast" Skeel 2003). DIP financing has, however, only been applied since 1990 (see Table 6, Panel A, in Bharath, Panchapegesan, and Wernel2010), which therefore marks the year of significant change in the process and outcome of Chapter 11 cases. 
Table 10

Out-of-sample tests: Portfolio-level regressions

\begin{tabular}{|c|c|c|c|c|c|c|c|c|}
\hline & Model 2 & Model 3 & Model 2 & Model 3 & Model 2 & Model 3 & Model 2 & Model 3 \\
\hline Alpha & $2.19^{* *}$ & 0.51 & 0.09 & -0.35 & -0.11 & -0.01 & $1.94^{* * * *}$ & $1.75^{* * *}$ \\
\hline$t$-statistic & {$[2.55]$} & {$[1.50]$} & {$[0.20]$} & {$[0.83]$} & {$[0.28]$} & {$[0.03]$} & {$[3.10]$} & [4.13] \\
\hline Market beta & $0.47^{* *}$ & 0.04 & -0.08 & -0.12 & 0.05 & $0.23^{\text {**** }}$ & -0.12 & -0.05 \\
\hline$t$-statistic & {$[2.54]$} & {$[0.53]$} & {$[0.83]$} & {$[1.13]$} & {$[0.63]$} & {$[2.94]$} & {$[0.68]$} & {$[0.39]$} \\
\hline Value beta & & $0.93^{* * *}$ & & $0.36^{* *}$ & & $0.63^{* * * *}$ & & $1.09^{* * * *}$ \\
\hline$t$-statistic & & {$[6.75]$} & & {$[2.21]$} & & [3.59] & & [6.29] \\
\hline Size beta & & $1.20^{* * * *}$ & & $0.75^{* * *}$ & & $0.49^{* * * *}$ & & $1.13^{* * * *}$ \\
\hline$t$-statistic & & {$[9.76]$} & & {$[5.09]$} & & {$[3.32]$} & & {$[6.42]$} \\
\hline Momentum beta & & $-0.70^{* * *}$ & & $-0.51^{* * *}$ & & $-0.37^{* * *}$ & & $-0.26^{*}$ \\
\hline$t$-statistic & & {$[6.58]$} & & {$[3.95]$} & & [3.19] & & [1.84] \\
\hline Observations & 46 & 46 & 46 & 46 & 60 & 60 & 60 & 60 \\
\hline Model & CAPM & Carhart & CAPM & Carhart & CAPM & Carhart & CAPM & Carhart \\
\hline Time period & $1975-1978$ & $1975-1978$ & 1981-1984 & 1981-1984 & $1985-1989$ & $1985-1989$ & 1990-1994 & 1990-1994 \\
\hline
\end{tabular}

For this table, we sort stocks into quintiles according to their default measure. We show the results from the regression of equal-weighted excess returns of monthly-updated long-short portfolios over the risk-free rate investing in the riskiest $20 \%$ and selling the safest $20 \%$ of stocks over the risk-free rate on the market premium in columns labeled Model 2, and a four-factor model ( $\left.M K T \_R F, H M L, S M B, U M D\right)$ in columns labeled Model 3. We skip one month between portfolio formation and returns. The top of the table provides information on the time period spanned by the respective estimation. The bottom of the table provides information on the factor model applied, the sample period, portfolio updating frequency, and portfolio weighting. Further details on the estimations are provided in the text. * indicates statistical significance at the $10 \%$ level, $* *$ at the $5 \%$ level, and $* * *$ at the $1 \%$ level.

incentives with maximization of debt value, for example, by tying management compensation to the duration of and the firm's performance in the reorganization process (see Skeel 2003). As a consequence, KERPs also contributed to the increase in bargaining power of creditors in the 1990s.

This change of Chapter 11 provides an additional event to study the impact of bargaining power on risk premia. Two predictions emerge for these out-ofsample tests. First, risk premia during the 1985-1989 period should be similar to the ones during the 1979-1984 period, as the increase in creditor bargaining power only emerges in the 1990s. Second, shareholders should be exposed to higher risk in distress in the 1990s due to the loss in bargaining power, associated with significant reductions in APR violations (see Bharath, Panchapegesan, and Werner 2010).

To test these predictions, we estimate the models reported in Table 7 for the 1985-1989 and the 1990-1994 periods. Table 10 shows the results. Columns 1-4 display the results for the main 1975-1979 and 1981-1984 samples from Table 7 As predicted, the CAPM alpha and beta during the 1985-1989 period are similar to the 1981-1984 period (columns 5). For the four-factor model, alpha and size and value factor loadings are also similar to the 1981-1984 period (column 6). During the 1990-1994 period when creditors experienced a recovery in bargaining power, the risk premium on distressed stocks increases to significantly positive values, similar to the period before the BRA. While the CAPM beta is rather low during the 1990-1994 period compared with the period before the BRA, the loadings on the value and size factors also increase back to levels similar to the pre-BRA period (columns 9 and 10). Taken together, the results in Table 10 establish that the reversal of the increase in shareholder 
Table 11

Sample of bankruptcy cases

\begin{tabular}{lccl} 
Company name & APR deviations in $\%$ & APR dummy & Paper(s) \\
\hline Allied Supermarkets & 45.50 & 1 & FT \\
Allied Technology & 0.43 & 1 & EMR \\
Bobbie Brooks & 6.34 & 1 & FT, EMR, W \\
Bohack & 0.98 & 1 & FT \\
Colonial Commercial & 21.89 & 1 & EMR \\
Commonwealth Oil Refining Co. & 3.50 & 1 & FT \\
Computer Communications & 3.53 & 1 & EMR \\
HRT Industries & 5.88 & 1 & EMR, W \\
Inforex & 3.43 & 1 & FT, EMR \\
KDT Industries & 4.61 & 1 & EMR, W \\
Leisure Dynamics & 24.63 & 1 & EMR \\
Lionel Corp. & 4.93 & 1 & EMR, W \\
Partners Oil & 8.01 & 1 & EMR \\
Penn-Dixie Industries & 5.10 & 1 & FT, EMR, W \\
Revere Copper \& Brass & 3.00 & 1 & FT, EMR, W \\
Richton International & 28.14 & 1 & EMR, W \\
Saxon Industries & 38.00 & 1 & FT, EMR, W \\
Seatrain Lines & 1.42 & 1 & EMR, W \\
Steelmet & 0.90 & 1 & EMR \\
Threshold Technology & 12.02 & 1 & EMR \\
Victor Technologies & 35.71 & 1 & EMR \\
\hline Braniff International & 0.00 & 0 & FT, EMR \\
Continental Airlines & 0.00 & 0 & FT, EMR \\
Daylin & 0.00 & 0 & FT \\
Evans Products & 0.00 & 0 & EMR, W \\
Interstate Stores & 0.00 & 0 & FT \\
J.W. Mays & 0.00 & 0 & EMR \\
Kenilworth & 0.00 & 0 & EMR \\
Storage Technology & 0.00 & 0 & EMR \\
\hline This table & 15 s & 1 & \\
\hline
\end{tabular}

This table lists the bankruptcy cases collected from Franks and Torous 1989) (FT). Eberhart, Moore, and Roenfeldt 1990) (EMR), andWeiss 1990) (W). We include all cases for which we can match the firm to COMPUSTAT and CRSP. Column 4 displays the paper which the case is taken from. For the APR violations we rely on FT and EMR, since they compute actual deviations from the APR, while W documents only whether there are deviations from APR or not. In cases of appearance in both FT and EMR, we list the FT values.

bargaining power in the 1990s leads to an increase in alphas and size and value betas, back to levels similar to those seen before the reform 24

Finally, the BAA-AAA spread is lower in the 1990s than in the 1980s, which is in line with creditors regaining bargaining power and opposite to the increase in risk premia for shareholders. For their 1994-1999 sample period, Davydenko and Strebulaev (2007) show that cross-sectional differences in credit spreads for distressed firms with different levels of firm-level shareholder bargaining power are significant again, similar to our pre-reform period.

\subsection{The effect of actual APR violations on stock returns}

To provide additional evidence on the relationship between distress risk premia and shareholder bargaining power, we use data on actual APR violations of firms in Chapter 11. We obtain stock returns in CRSP for 29 of these firms during our sample period (see Table 11). For each firm, we identify the maximum of

24 In an earlier version of the paper we also report results for the complete 1990-2009 period, which are qualitatively similar to the 1990-1994 period. 
Table 12

Distress risk premia and deviations from the APR

\begin{tabular}{lcccccc} 
& 1 & 2 & 3 & 4 & 5 & 6 \\
\hline APR dummy & $-0.1460^{* *}$ & $-0.1560^{* *}$ & $-0.2629^{* *}$ & $-0.0837^{* *}$ & $-0.0946^{*}$ & $-0.1568^{*}$ \\
$t$-statistic & {$[2.46]$} & {$[2.12]$} & {$[2.25]$} & {$[2.25]$} & {$[1.92]$} & {$[1.94]$} \\
\hline Observations & 410 & 277 & 145 & 410 & 277 & 145 \\
Firms & 29 & 29 & 29 & 29 & 29 & 29 \\
Months & 24 & 12 & 6 & 24 & 12 & 6 \\
Model & Carhart & Carhart & Carhart & Unadjusted & Unadjusted & Unadjusted \\
\hline
\end{tabular}

This table shows the $\beta$ estimates of the regression $r e t_{i t}=\alpha+\beta \cdot A P R d u m m y_{i}+\epsilon_{i t}$ with $t$-statistics in parentheses, where APR dummy is a dummy variable taking the value of one if firm $i$ features positive deviations from the APR in Chapter 11 reorganization and zero otherwise. For each firm $i$, we identify the maximum of the default risk measure and regress the monthly returns from the following 24, 12, and 6 months on the APR dummy for all firms. The Carhart model is a four-factor model controlling for market return, size, book-to-market ratio, and momentum. * indicates statistical significance at the $10 \%$ level, and $* *$ at the $5 \%$ level.

its default risk measure. We regress the firm's stock returns for the 24,12 , and 6 months after the maximum of its default risk measure on an APR dummy, taking the value of one if the firm exhibits deviations from absolute priority in Chapter 11 reorganizations. We examine both raw returns and returns adjusted for market, size, value and momentum factors. The interpretation of the results requires the standard assumption that observed returns are, on average, a proxy for expected returns, which might be less innocuous in smaller samples.

Table 12 shows the results. Columns 1-3 show findings for adjusted returns. For the 24 months after reaching the maximum of the default risk measure, firms with APR violations earn reliably lower monthly returns by $14.60 \%$ compared with firms without APR deviations. The magnitude of this effect is stronger when looking at a shorter interval of monthly returns after the maximum default risk. The results for unadjusted returns are in columns 4-6. For the 24 months after the firm reaches its maximum default risk, firms with APR violations earn significantly lower monthly returns by $8.37 \%$. The magnitude also increases for unadjusted returns for shorter intervals. Thus, stockholders of firms that exhibit APR violations in bankruptcy proceedings demand lower distress risk premia. These results highlight the connection between shareholder recovery and return expectations, and therefore reinforce the view that shareholder bargaining power is an important factor for distress risk premia in the cross-section of stock returns.

\section{Conclusion}

This paper examines distress risk premia around a bankruptcy reform that shifts bargaining power in financial distress from debtholders to shareholders. We find that the reform reduces risk factor loadings and returns of distressed stocks. The effect is stronger for firms with lower firm-level shareholder bargaining power. An increase in credit spreads of riskier relative to safer firms, in particular for firms with lower firm-level shareholder bargaining power, confirms a shift in bargaining power from bondholders to shareholders. Out-of-sample tests reveal 
that a reversal of the reform's effects leads to a reversal of risk factor loadings and returns.

The paper makes three contributions. First, we provide evidence on how the allocation of bargaining power in distress affects the riskiness of different securities (stocks and bonds) and risk premia demanded by holders of those securities. Providing a better understanding of this mechanism can help to design optimal bankruptcy codes. Second, the significant reduction in risk premia for distressed stocks due the BRA suggests that investors demand a positive distress risk premium. However, our findings are not meant to resolve the distress risk premium puzzle that finds consistently negative risk premia on distressed stocks; see, for example, Opp 2012) and Ozdagl 2013) for recent attempts to resolve this puzzle. Third, the major role attributed to creditor rights, according to the law and finance literature, is that they empower creditors to enforce their contracts. Notably, La Porta et al. 1997, 1998) argue that legal protection supports financial development by lowering the cost of borrowing. Our findings underline that changes in creditor rights can have more subtle implications than previously suggested. In the case of the BRA, a weaker position of creditors in financial distress is associated with higher bond yields, but it leads to lower funding costs for equity (i.e., lower equity premia). While we make no claim about the net effect on external funding costs due to the BRA, our results suggest that changes in creditor rights can have more complex consequences than current literature suggests, and would therefore be an interesting topic for future research.

\section{Appendix A. Financial Distress, Stock Returns, and Yield Spreads}

To study the implications of distress risk for stock returns and yield spreads before and after the bankruptcy reform, we employ the Fan and Sundaresan 2000) model (FS), which is based on the Leland 1994 model of risky infinite-maturity debt, to study the asset pricing implications of strategic debt service with varying degrees of equityholders' bargaining power vis-à-vis creditors in renegotiations. Given that the bankruptcy reform affects all firms similarly, but there is no a priori reason for all firms to have similar bargaining positions in renegotiations, we consider two bargaining parameters (i.e., $\eta_{i}$ and $\eta_{r}$ ) with varying degrees of complementarity (i.e., $\gamma_{i}$ )25

While FS address numerous issues, the simplest version of their model - transformed into an earnings-based setting as in Hackbarth. Hennessy, and Leland 2007 - is sufficient for deriving asset pricing implications that follow from the bankruptcy reform. At every point in time $t>0$, each firm in the economy owns machines that generate uncertain earnings, $X_{t}$, which evolve over time according to a geometric Brownian motion with drift $\mu$ under the physical measure, volatility $\sigma$, and an initial value $X_{0}>0$ at $t=0$. Furthermore, firms cannot sell their assets to pay dividends, the risk-free interest rate is $r$, and the economy's pricing kernel, $\Lambda_{t}$, follows a geometric Brownian motion with volatility $\sigma_{\Lambda}$ and correlation $\rho$ with $X_{t}$, characterizing the economy's risk-reward trade-off.

25 This specification differs with respect to the literature (e.g., Davydenko and Strebulaev 2007). By modeling the renegotiation game in a reduced-form way, $\eta$ is essentially a sufficient statistic for, e.g., the risk of renegotiation failure, liquidation costs, and pure Nash bargaining power, and equals the actual share of the surplus that goes to debtors. 
Consider a firm with a single class of risky debt with an instantaneous, perpetual coupon $C$ per unit of time. When the firm pays its contractual coupon, it receives tax benefits $\tau C$ per unit of time. With the tax shield, the value of the levered firm is always larger than the value of the unlevered firm, as long as the firm is not liquidated. If the firm defaults non-strategically, claims are settled, tax benefits are lost, and liquidation costs proportional to unlevered firm value, $\alpha$, are incurred. Strategic default, however, optimally occurs to avoid liquidation when the firm's earnings fall below an endogenously determined threshold $X_{S}$. At that point, equityholders stop making the contractual payments to debtholders but keep control of the firm, servicing the debt strategically until the earnings process returns above the threshold for strategic debt service $X_{S} 26$

In case of strategic debt service, equityholders and debtholders enter into a Nash bargaining game, in which they split the levered firm value according to their bargaining powers $\eta$ and $1-\eta$, and use liquidation values 0 and $(1-\alpha)(1-\tau) X /(r-\hat{\mu})$ as disagreement point, where $\hat{\mu}=\mu+\rho \sigma \sigma_{\Lambda}$ is the risk-neutral drift for which a regularity condition requires that $\hat{\mu}<r$. Recall that prior to the reform $\eta=\eta_{i}$ and equityholders' bargaining power potentially rises at the time of the reform:

$$
\eta=\left\{\begin{array}{ll}
\eta_{i} & \text { before the reform } \\
\eta_{i}+\eta_{r}-\gamma_{i} \cdot \min \left\{\eta_{i}, \eta_{r}\right\} & \text { after the reform }
\end{array},\right.
$$

where $\gamma_{i} \in[0,1]$ is the degree of complementarity of reform's $\eta_{r}$ relative to firm $i$ 's $\eta_{i}$. In particular, a low (high) value of $\gamma_{i}$ means that the BRA's effect is more complementary (substitutable). Finally, to ensure that $\eta \in[0,1]$ after the reform, we assume that $0 \leq \eta_{i} \leq \frac{1}{2}$ and $0 \leq \eta_{r} \leq \frac{1}{2}$, which is consistent with the evidence on stricter adherence to the absolute priority rule prior to the BRA.

To derive equity value, $E(X)$, we first need to derive levered firm value, $v(X)$, because it determines the bargaining surplus of the bargaining game. Standard arguments imply that the value of the levered firm, $v(X)$, satisfies two ordinary differential equations (ODEs):

$$
\begin{aligned}
\frac{1}{2} \sigma^{2} X^{2} v^{\prime \prime}(X)+\hat{\mu} X v^{\prime}(X)+(1-\tau) X+\tau C-r v(X) & =0 \text { if } X \geq X_{S}, \\
\frac{1}{2} \sigma^{2} X^{2} v^{\prime \prime}(X)+\hat{\mu} X v^{\prime}(X)+(1-\tau) X-r v(X) & =0 \text { if } X<X_{S} .
\end{aligned}
$$

The two ODEs are solved subject to suitable boundary conditions (see Lemma 1 in FS):

$$
\begin{aligned}
& \lim _{X \uparrow \infty} v(X)=\frac{(1-\tau) X}{r-\hat{\mu}}+\frac{\tau C}{r}, \\
& \lim _{X \uparrow X_{S}} v(X)=\lim _{X \downarrow X_{S}} v(X), \\
& \lim _{X \uparrow X_{S}} v^{\prime}(X)=\lim _{X \downarrow X_{S}} v^{\prime}(X), \\
& \lim _{X \downarrow 0} v(X)=0 .
\end{aligned}
$$

Solving the problem yields the value of the levered firm under the risk-neutral (pricing) measure:

$$
v(X)= \begin{cases}\frac{(1-\tau) X}{r-\hat{\mu}}+\frac{\tau C}{r}-\frac{\lambda_{+}}{\lambda_{+}-\lambda_{-}} \frac{\tau C}{r}\left(\frac{X}{X_{S}}\right)^{\lambda_{-}} & \text {if } X \geq X_{S}, \\ \frac{(1-\tau) X}{r-\hat{\mu}}-\frac{\lambda_{-}}{\lambda_{+}-\lambda_{-}} \frac{\tau C}{r}\left(\frac{X}{X_{S}}\right)^{\lambda_{+}} & \text {if } X<X_{S},\end{cases}
$$

26 When debt renegotiation is feasible in a jump-diffusion model, such as Leland 2006, our predictions for stock returns of distressed firms also obtain in the presence of non-strategic default following from intensity-based (jump) risk. 
where the positive and negative characteristic roots of the ODEs are given by:

$$
\lambda_{ \pm}=\left(\frac{1}{2}-\hat{\mu} / \sigma^{2}\right) \pm \sqrt{\left(\frac{1}{2}-\hat{\mu} / \sigma^{2}\right)^{2}+2 r / \sigma^{2}} .
$$

Similarly, equity value, $E(X)$, satisfies the following ODE in the non-renegotiation region:

$$
\frac{1}{2} \sigma^{2} X^{2} E^{\prime \prime}(X)+\hat{\mu} X E^{\prime}(X)+(1-\tau)(X-C)-r E(X)=0 \quad \text { if } X \geq X_{S},
$$

and equity value in that region solves the boundary conditions (see Proposition 3 in FS):

$$
\begin{aligned}
& \lim _{X \uparrow \infty} E(X)=(1-\tau)\left(\frac{X}{r-\hat{\mu}}-\frac{C}{r}\right), \\
& \lim _{X \downarrow X_{S}} E(X)=\eta\left(\frac{\alpha(1-\tau) X_{S}}{r-\hat{\mu}}+\frac{-\lambda_{-}}{\lambda_{+}-\lambda_{-}} \frac{\tau C}{r}\right), \\
& \lim _{X \downarrow X_{S}} E^{\prime}(X)=\eta\left(\frac{\alpha(1-\tau)}{r-\hat{\mu}}+\frac{-\lambda_{-} \lambda_{+}}{\lambda_{+}-\lambda_{-}} \frac{\tau C}{r X_{S}}\right) .
\end{aligned}
$$

Solving yields equity value in the non-renegotiation region under the risk-neutral (pricing) measure:

$$
E(X)=(1-\tau)\left(\frac{X}{r-\hat{\mu}}-\frac{C}{r}\right)+\frac{(1-\tau) C}{\left(1-\lambda_{-}\right) r}\left(1+\frac{\eta \tau}{1-\tau} \frac{\lambda_{-}\left(\lambda_{+}-1\right)}{\lambda_{+}-\lambda_{-}}\right)\left(\frac{X}{X_{S}}\right)^{\lambda_{-}}
$$

where the threshold for strategic debt service, $X_{S}$, from the optimality condition in Equation A.13 equals:

$$
X_{S}=\frac{-\lambda_{-}}{1-\lambda_{-}} \frac{r-\hat{\mu}}{1-\tau} \frac{1-\tau+\eta \tau}{1-\eta \alpha} \frac{C}{r} .
$$

Next, we invoke the standard equilibrium condition that says $\mathrm{E}[d E / E]+[(1-\tau)(X-C)] / E-$ $r=-\operatorname{cov}[d E, d \Lambda]$. Using Ito's lemma and Equation A.14 to derive $d E$, we find $\mathrm{E}[\cdot]$ and $\operatorname{cov}[\cdot]$. Consequently, we also obtain a closed-form solution of equity's expected excess return, $E E R(X)$, for $X \geq X_{S}$ :

$$
E E R(X)=-\rho \sigma \sigma_{\Lambda} \beta_{E},
$$

where $-\rho \sigma \sigma_{\Lambda}$ is the risk premium of (unlevered) $X$-risk and where the equity beta is given by:

$$
\beta_{E}=1+\frac{(1-\tau) C}{r E(X)}-\frac{(1-\tau) C}{r E(X)}\left(1+\frac{\eta \tau}{1-\tau} \frac{\lambda_{-}\left(\lambda_{+}-1\right)}{\lambda_{+}-\lambda_{-}}\right)\left(\frac{X}{X_{S}}\right)^{\lambda_{-}} .
$$

The second and the third term on the ride-hand side of Equation A.17 are, respectively, the "standard leverage" effect and the "de-leverage" effect of shareholder bargaining power. While the former increases returns with default risk, the latter does the opposite, since for higher default risk, equityholders are more likely to exchange a risky (levered) equity position for less risky (unlevered) cash position.

Debt value, $D(X)$, in the non-renegotiation region is equal to $v(X)-E(X)$, which implies:

$$
D(X)=\frac{C}{r}\left(1-\frac{\lambda_{+}-\lambda_{-}\left(1+(1-\eta) \tau\left(\lambda_{+}-1\right)\right)}{\left(1-\lambda_{-}\right)\left(\lambda_{+}-\lambda_{-}\right)}\left(\frac{X}{X_{S}}\right)^{\lambda_{-}}\right) .
$$

As a result, the credit spread, $C S(X)=C / D(X)-r$, for $X \geq X_{S}$ is given by:

$$
C S(X)=\frac{\left(1-\lambda_{-}\right)\left(\lambda_{+}-\lambda_{-}\right) r}{\left(1-\lambda_{-}\right)\left(\lambda_{+}-\lambda_{-}\right)-\left[\lambda_{+}-\lambda_{-}\left(1-(1-\eta) \tau\left(1-\lambda_{+}\right)\right)\right]\left(\frac{X}{X_{S}}\right)^{\lambda_{-}}}-r,
$$

which increases (monotonically) with shareholder bargaining power. 
Finally, the $T$-year default probability under the physical measure is (see Harrison 1985):

$$
D P(X)=\Phi\left(\frac{\log \left(\frac{X_{S}}{X}\right)-\left(\mu-\frac{1}{2} \sigma^{2}\right) T}{\sigma \sqrt{T}}\right)+\left(\frac{X}{X_{S}}\right)^{1-2 \mu / \sigma^{2}} \Phi\left(\frac{\log \left(\frac{X_{S}}{X}\right)+\left(\mu-\frac{1}{2} \sigma^{2}\right) T}{\sigma \sqrt{T}}\right),
$$

for $X \geq X_{S}$, and where $\Phi(\cdot)$ is the standard normal distribution function. Figure 1 plots expected excess return in Equation A.16, which is largely determined by the three components of equity beta in Equation A.17, against default probability in Equation A.20 for various levels of firm $i$ 's shareholder bargaining power, $\eta_{i}$ and various degrees of reform complementarity, $\gamma_{i}$.

\section{Appendix B. Details on the Default Risk Estimation Procedure}

Throughout the paper we calculate default probabilities by the Campbell, Hilscher, and Szilagyi 2008) 12-months-ahead hazard model. The reported default probability is the likelihood of default at time $t+12$ given survival until $t+11$. Accordingly, it cannot be interpreted as the likelihood of default within the next 12 months, as, for example, Moody's EDF. However, for our analysis the relevant exercise is the ordering of firms according to their default risk. The calculation of an explicit default probability over a distinct period of time is not necessary. Campbell, Hilscher, and Szilagyi 2008) consider several accounting and market-based explanatory variables to predict default in their model.

All variables are calculated using annual COMPUSTAT as well as monthly and daily CRSP data. Accounting variables are taken from the most recent fiscal year ending, and market variables are updated on a monthly basis. We update the computation of the default probability every month. Below are the variable definitions taken from Campbell, Hilscher, and Szilagvi 2008, 27

$$
\begin{aligned}
& \operatorname{RSIZE}_{i, t}=\log \left(\frac{\text { Firm Market Equity }_{i, t}}{\text { Total S\&P500 Market Value }_{t}}\right) \\
& \operatorname{EXRET}_{i, t}=\log \left(1+R_{i, t}\right)-\log \left(1+R_{S \& P 500, t}\right) \\
& \operatorname{NIMTA}_{i, t}=\frac{\text { Net Income }_{i, t}}{\text { Firm Market Equity }_{i, t}+\text { Total Liabilities }_{i, t}} \\
& \text { TLMTA }_{\text {it }}=\frac{\text { Total Liabilities }_{i, t}}{\text { Firm Market Equity }_{i, t}+\text { Total Liabilities }_{i, t}} \\
& \text { CASHMTA }_{i t}=\frac{\text { Cash and Short Term Investments }}{i, t} \\
& \operatorname{SIGMA}_{i t}=\left(252 * \frac{1}{N-1} \sum_{j=1}^{3} r_{i, t-j}^{2}\right)^{\frac{1}{2}}
\end{aligned}
$$

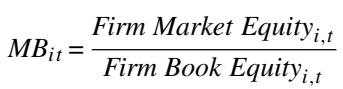

27 For an extended explanation and motivation for the variables, please refer to the paper by the authors. The EXRET variable enters the model in a modified version as a geometrically weighted average of the past return from $t-1$ to $t-12$ as in the original model. For NIMTA we do not calculate a similar weighted average since we use the annual value-weighting each quarter equally. 
The default probability is finally calculated as:

$$
D P_{t}\left(Y_{i t+12}=1 \mid Y_{i t+11}=0\right)=\frac{1}{1+\exp \left(-\alpha_{j}-\beta_{j} x_{i t}\right)}
$$

where the coefficients $\alpha_{j}$ and $\beta_{j}$ are estimated exclusively with historically available data at the time of computation of default probability to avoid a look-ahead bias. Thus, the coefficients are updated annually with an increasing number of observations. We also apply the updated model each year. Since the updated model is only available from 1981, we apply the 1981 model to the years before, which allows us to minimize the look-ahead bias as much as possible. Like Campbell, Hilscher, and Szilagyi 2008) we winsorize the variables at the 5/95 percentile interval to eliminate outliers that might influence the results.

\section{References}

Acharya, V. V., S. T. Bharath, and Srinivasan, A. 2007. Does industry-wide distress affect defaulted firms? Evidence from creditor recoveries. Journal of Financial Economics 85:787-821.

Alderson, M. J. and B. L. Betker. 1996. Liquidation costs and accounting data. Financial Management 25:25-36.

Asquith, P., R. Gertner, and D. Scharfstein. 1994. Anatomy of financial distress: An examination of junk-bond issuers. Quarterly Journal of Economics 109:625-58.

Ayotte, K. and E. R. Morrison. 2009. Creditor control and conflict in Chapter 11. Journal of Legal Analysis $1: 511-51$.

Bebchuk, L. A. 1998. Chapter 11. NBER Working Paper 6473, National Bureau of Economic Research.

2002. Ex ante costs of violating absolute priority in bankruptcy. Journal of Finance 57:445-60.

Bebchuk, L. A., and H. F. Chang. 1992. Bargaining and the division of value in corporate reorganization. Journal of Law, Economics, and Organization 8:253-79.

Bergman, Y. Z. and J. L. Callen. 1991. Opportunistic underinvestment in debt renegotiation and capital structure. Journal of Financial Economics 29:137-71.

Betker, B. L. 1995. Management's incentives, equity's bargaining power, and deviations from absolute priority in Chapter 11 bankruptcies. Journal of Business 68:161-83.

Bharath, S. T., V. Panchapegesan, and I. Werner. 2010. The changing nature of Chapter 11. Working Paper, Ohio State University.

Bradley, M., and M. Rosenzweig. 1992. The untenable case for Chapter 11. Yale Law Journal 101:1043-95.

Broude, R. F. 1984. Cramdown and Chapter 11 of the bankruptcy code: The settlement imperative. Business Lawyer 39:1341-77.

Campbell, J. Y., J. Hilscher, and J. Szilagyi. 2008. In search of distress risk. Journal of Finance 63:2899-939.

Carhart, M. M. 1997. On persistence in mutual fund performance. Journal of Finance 52:57-82.

Chan, K. C., and N.-F. Chen. 1991. Structural and return characteristics of small and large firms. Journal of Finance 46:1467-84.

Cohen, R. B., C. Polk, and T. Vuolteenaho. 2003. The value spread. Journal of Finance 58:609-42.

Davydenko, S. A., and J. R. Franks. 2008. Do bankruptcy codes matter? A study of defaults in France, Germany, and the U.K. Journal of Finance, 63:565-608.

Davydenko, S. A., and I. A. Strebulaev. 2007. Strategic actions and credit spreads: An empirical investigation. Journal of Finance 62:2633-71.

Djankov, S., O. Hart, C. McLiesh, and A. Shleifer. 2008. Debt enforcement around the world. Journal of Political Economy 116:1105-49. 
Eberhart, A. C., W. T. Moore, and R. L. Roenfeldt. 1990. Security pricing and deviations from the absolute priority rule in bankruptcy proceedings. Journal of Finance 45:1457-69.

Fama, E. F., and J. D. MacBeth. 1973. Risk, return, and equilibrium: Empirical tests. Journal of Political Economy $81: 607-36$

Fan, H., and S. M. Sundaresan. 2000. Debt valuation, renegotiation, and optimal dividend policy. Review of Financial Studies 13:1057-99.

Favara, G., E. Schroth, and P. Valta. 2012. Strategic Default and Equity Risk Across Countries. Journal of Finance 67:2051-95.

François, P., and E. Morellec. 2004. Capital structure and asset prices: Some effects of bankruptcy procedures. Journal of Business 77:387-412.

Franks, J. R., and W. N. Torous. 1989. An empirical investigation of u.s. firms in reorganization. Journal of Finance 44:747-69.

Franks, J. R., and W. N. Torous. 1994. A comparison of financial recontracting in distressed exchanges and Chapter 11 reorganizations. Journal of Financial Economics 35:349-70.

Garlappi, L., T. Shu, and H. Yan. 2008. Default risk, shareholder advantage, and stock returns. Review of Financial Studies 21:2743-78.

Gilson, S. C., K. John, and L. H. P. Lang 1990. Troubled debt restructurings: An empirical study of private reorganization of firms in default. Journal of Financial Economics 27:315-53.

Hackbarth, D., C. A. Hennessy, and H. E. Leland. 2007. Can the tradeoff theory explain debt structure? Review of Financial Studies 20:1389-428.

Harrison, J. M. 1985. Brownian Motion and Stochastic Flow Systems. New York: John Wiley and Sons.

Hart, O., and J. Moore. 1994. A theory of debt based on the inalienability of human capital. Quarterly Journal of Economics 109:841-79.

Kaplan, H. L. 1987. Bankruptcy as a corporate management tool. ABA Journal 1:64-7.

Kerkman, J. R. 1987. The debtor in full control: A case for adoption of the trustee system. Marquette Law Review 70:159-209.

King, L. P. 1979. Chapter 11 of the 1978 bankruptcy code. American Bankruptcy Law Journal 53:107-32.

Klee, K. 1979. All you ever wanted to know about cram down under the new bankruptcy code. American Bankruptcy Law Journal 53:133-71.

275-98.

1980. Legislative history of the new bankruptcy law. American Bankruptcy Law Journal 54:

La Porta, R., F. Lopez-de-Silanes, A. Shleifer, and R. W. Vishny. 1997. Legal determinants of external finance. Journal of Finance 52:1131-50.

1998. Law and finance. Journal of Political Economy 106:1113-55.

Leland, H. E. 1994. Corporate debt value, bond covenants, and optimal capital structure. Journal of Finance 49:1213-52.

2006. A new structural model. Princeton lecture series in finance,, Lecture 2.

LoPucki, L. M. 1983. Debtor in full control: System failure under Chapter 11 of the bankruptcy code. American Bankruptcy Law Journal 57:99-126.

1995. Chapter 11: An agenda for basic reform. American Bankruptcy Law Journal 69:573-82.

LoPucki, L. M., and W. C. Whitford. 1990. Bargaining over equity's share in the bankruptcy reorganization of large, publicly held companies. University of Pennsylvania Law Review 139:125-96. 
Lyandres, E., and A. Zhdanov. 2013. Investment opportunities and bankruptcy prediction. Journal of Financial Markets 16:439-76.

MacKinley, C. 1997. Event studies in economics and finance. Journal of Economic Literature 35:13-39.

Newey, W. K., and K. D. West. 1987. A simple, positive semi-definite, heteroskedasticity and autocorrelation consistent covariance matrix. Econometrica 55:703-08.

Opler, T. C., and S. Titman. 1994. Financial distress and corporate performance. Journal of Finance 49:1015-40.

Opp, C. 2012. Learning, active investors, and the returns of financially distressed firms. Working Paper, University of Pennsylvania.

Ozdagli, A. 2013. Distressed, but not risky: Reconciling the empirical relationship between financial distress, market-based risk indicators, and stock returns (and more). Working Paper, Federal Reserve Bank of Boston.

Posner,E. A. 1997. The political economy of the bankruptcy reform act of 1978. Michigan Law Review 96:47-126.

Rodano, G., N. Serrano-Velarde, and E. Tarantino. 2014. Bankruptcy law and bank financing. Working Paper, University of Mannheim.

Scott, J. A., and T. C. Smith. 1986. The effect of the Bankruptcy Reform Act of 1978 on small business loan pricing. Journal of Financial Economics 16:119-40.

Shumway, T. 2001. Forecasting bankruptcy more accurately: A simple hazard model. Journal of Business 74:10124.

Skeel, D. 2003. Creditors' ball: The 'new' new corporate governance in Chapter 11. University of Pennsylvania Law Review 152:917-51.

Valta, P. Forthcoming. Strategic default, debt structure, and stock returns. Journal of Financial and Quantitative Analysis.

Weiss, L. A. 1990. Bankruptcy resolution: Direct costs and violation of priority of claims. Journal of Financial Economics 27:285-314.

Weiss, L. A., and K. H. Wruck. 1998. Information problems, conflicts of interest, and asset stripping: Chapter 11's failure in the case of eastern airlines. Journal of Financial Economics 48:55-97.

White, M. J. 1983. Bankruptcy costs and the new bankruptcy code. Journal of Finance 38:477-88.

White, M. J. 1989. The corporate bankruptcy decision. Journal of Economic Perspectives 3:129-51. 